Research, Society and Development, v. 9, n. 11, e100291111268, 2020

(CC BY 4.0) | ISSN 2525-3409 | DOI: http://dx.doi.org/10.33448/rsd-v9i11.11268

\title{
Caiçara: a lepra nos destinos femininos ${ }^{1}$ \\ Caiçara: leprosy in women's destinations \\ Caiçara: la lepra en los destinos de las mujeres
}

Recebido: 16/12/2020 | Revisado: 18/12/2020 | Aceito: 23/12/2020 | Publicado: 23/12/2020

Luciano Marcos Curi

ORCID: https://orcid.org/0000-0001-7309-0578

Instituto Federal de Educação, Ciência e Tecnologia do Triângulo Mineiro, Brasil

E-mail: lucianocuri@iftm.edu.br

Vera Lucia Puga

ORCID: https://orcid.org/0000-0003-1890-2355

Universidade Federal de Uberlândia, Brasil

E-mail: puga.veralucia@gmail.com

Ana Carolina Pires das Dôres

ORCID: https://orcid.org/0000-0001-7607-6093

Universidade Estadual Paulista "Júlio de Mesquita Filho", Brasil

E-mail: anacarolpires0@gmail.com

Fábia Núbia Moura e Silva

ORCID: https://orcid.org/0000-0002-3505-0839

Instituto Federal de Educação, Ciência e Tecnologia do Triângulo Mineiro, Brasil

E-mail: fabianmoura.adv@outlook.com

\section{Resumo}

O presente artigo refere-se à história da lepra no Brasil observada a partir de um filme brasileiro de 1950, período áureo do isolamento dos leprosos no país e no mundo. A história de uma época flagrada numa peça artística-cultural produzida para o entretenimento, onde se desvela comportamentos e mentalidades que levaram ao exílio sanitário dos leprosos no Brasil. Para compreender tanto o filme quanto o seu enredo procurou-se articular e combinar as recentes pesquisas sobre a lepra no Brasil e no mundo aos estudos feministas, com o objetivo de esclarecer a personagem central que se trata de uma jovem, filha de leprosos isolados, e atingida diretamente pelo flagelo que assolou sua família. A pesquisa objetivou então compreender a história da lepra por uma fonte até então subutilizada pelos historiadores 
e demais estudiosos do assunto. Tratou-se de uma pesquisa qualitativa, exploratória, bibliográfica e documental realizada em fontes primárias e secundárias, além do próprio filme, que procurou articular a história da lepra as pesquisas sobre feminismo. Concluiu-se que a lepra durante a maior parte do século XX infundia um medo coletivo incompatível com sua real periculosidade, porém, compreensível a luz da sua longa história de discriminação alimentada por preconceitos religiosos e culturais desde o mundo antigo. Enfim, uma época em que a lepra se revestia de medos e tabus compreensíveis apenas sob a luz de sua longa história. Uma época em que a atual hanseníase ainda não existia, pois estava em gestação.

Palavras-chave: Lepra; Hanseníase; Cinema brasileiro; Cinema; Educação.

\section{Abstract}

The present article refers to the history of leprosy in Brazil observed from a Brazilian film from 1950, the golden period of the isolation of lepers in the country and in the world. The story of an era caught in an artistic-cultural piece produced for entertainment, where behaviors and mentalities that led to the sanitary exile of lepers in Brazil are unveiled. To understand both the film and its plot, we sought to articulate and combine recent research on leprosy in Brazil and the world with feminist studies, with the aim of clarifying the central character that is a young woman, the daughter of isolated lepers, and directly affected by the scourge that devastated his family. The research then aimed to understand the history of leprosy from a source hitherto underutilized by historians and other scholars on the subject. It was a qualitative, exploratory, bibliographic and documentary research carried out in primary and secondary sources, in addition to the film itself, which sought to articulate the history of leprosy with research on feminism. It was concluded that leprosy during most of the twentieth century instilled a collective fear incompatible with its real dangerousness, however, understandable in light of its long history of discrimination fueled by religious and cultural prejudices since the ancient world. In short, a time when leprosy was filled with fears and taboos that were understandable only in the light of its long history. A time when the current hansen's disease did not yet exist, as it was in gestation.

Keywords: Leprosy; Hansen's disease; Brazilian cinema; Cinema; Education.

\section{Resumen}

El presente artículo se refiere a la historia de la lepra en Brasil observada a partir de una película brasileña de 1950, el período dorado del aislamiento de los leprosos en el país y en el mundo. La historia de una época atrapada en una pieza artístico-cultural producida para el entretenimiento, donde se develan comportamientos y mentalidades que llevaron al exilio 
sanitario de los leprosos en Brasil. Para comprender tanto la película como su trama, buscamos articular y combinar investigaciones recientes sobre la lepra en Brasil y el mundo con estudios feministas, con el objetivo de esclarecer el personaje central que es una mujer joven, hija de leprosos aislados, y directamente afectado por el flagelo que asoló a su familia. Luego, la investigación tuvo como objetivo comprender la historia de la lepra a partir de una fuente hasta ahora infrautilizada por historiadores y otros estudiosos sobre el tema. Se trató de una investigación cualitativa, exploratoria, bibliográfica y documental realizada en fuentes primarias y secundarias, además de la propia película, que buscó articular la historia de la lepra con la investigación sobre el feminismo. Se concluyó que la lepra durante la mayor parte del siglo XX infundió un miedo colectivo incompatible con su peligrosidad real, comprensible sin embargo a la luz de su larga historia de discriminación alimentada por prejuicios religiosos y culturales desde el mundo antiguo. En definitiva, una época en la que la lepra estaba llena de temores y tabúes que solo eran comprensibles a la luz de su dilatada trayectoria. Una época en la que la actual enfermedad de Hansen aún no existía, ya que estaba en gestación.

Palabras clave: Lepra; Enfermedad de hansen; Cine brasileño; Cine; Educación.

\section{Considerações Iniciais: cinema e lepra}

No ano de 2020 o Brasil e o mundo foram arrebatados por um acontecimento inusitado: a pandemia do novo coronavírus. O surgimento desta nova doença obrigou boa parte da população mundial e brasileira a ficarem em isolamento social, trancados em casa, suspenderam-se as aulas e fechou-se o comércio, interromperam-se todas as atividades coletivas. Medo e apreensão tornaram-se palavras cotidianas.

Muitas pessoas ficaram consternadas de terem suas vidas alteradas por alguns meses, muitos queixaram-se dos prejuízos econômicos. Muito transtorno e desconcerto. Mas agora imaginem as pessoas vivendo em isolamento social até o último dos seus dias? Imaginem ter a vida alterada permanentemente em função da eclosão de uma doença? A vida nunca mais será a mesma. Nunca.

No passado a lepra era um pesadelo dessa envergadura para seus acometidos e familiares. Uma doença que levava ao isolamento obrigatório. Guardadas as devidas proporções, ressalvadas os momentos históricos diferentes e também as diferenças entre as duas doenças, o isolamento subjaz as duas experiências históricas. Para um historiador da lepra não deixa de ser surpreendente o desconhecimento coletivo das experiências históricas 
de outrora, nossa dificuldade em ver com clareza a gravidade do episódio atual, e nossa patente incapacidade de extrair lições do passado, aplicáveis ou não a atualidade.

A pesquisa aqui divulgada traz a público uma tentativa de aprofundar nossa compreensão sobre a história da lepra no Brasil e também no mundo. Para tanto foi escolhido um filme brasileiro como local de observação do que ocorria com os leprosos em meados do século XX. O cinema como fonte histórica e também como veículo cultural e educacional.

O cinema é um lugar privilegiado para se observar a sociedade, suas características e sua história. Embora, o cinema tenha sido concebido na sua origem para o entretenimento, suas potencialidades para outros fins logo foram percebidas. Os filmes encenam histórias que entretém e encantam multidões. Isso ocorre porque a sociedade vê nos filmes seus valores representados, suas expectativas e seus sonhos transpostos para uma linguagem vívida, prenhe de dinamicidade e movimento. O cinema é uma produção humana por excelência onde se satisfazem tanto nossas expectativas e medos com relação ao futuro quanto nossas curiosidades e anseios com relação ao passado. Enfim, é possível ver uma determinada sociedade através dos filmes que ela produz (Cf. Ferro, 1992).

Uma das potencialidades do cinema percebida já na década de 1930 foi suas contribuições para a Educação. Os filmes podem ser utilizados para educar, narrar os fatos do passado e fazer pensar. Logo percebeu-se que o cinema não era apenas um negócio lucrativo, mas poderia ser também um veículo de cultura e ensino. No Brasil, já em 1931, o país dispunha de uma obra dedicada ao assunto (Cf. Serrano \& Venâncio Filho, 1931). Foi uma obra pioneira sobre um assunto que até hoje gera debates (Cf. Campelo, 2007).

Desse modo, atualmente o entendimento de que o cinema é um veículo que pode colaborar com a Educação é bem aceito e está consolidado. Neste trabalho procurou-se explorar os aspectos representacionais e educacionais, no sentido de esclarecer o passado, de um filme brasileiro do ano de 1950.

Assim, o cinema é uma representação onde é possível investigar a sociedade que o produziu e também o que está retratado na película (Cf. Chartier, 1990; Le Goff, 1991; Baczko, 1985; Laplatine \& Trindade, 2000). Afinal retratante e retratados se revelam na obra fílmica. Neste sentido o cinema também pode ser uma fonte valiosa para a pesquisa histórica. Neste texto procurou-se também explorar essa dimensão. Utilizar um filme brasileiro como fonte para colaborar para compreender e para narrar à história dos leprosos no Brasil do século XX (Cf. Pinsky, 2005; Pinsky \& Luca, 2009; Montenegro, 2010). Trata-se do filme Caiçara (Direção de Adolfo Celi, 1950). 


\section{Metodologia}

Este artigo trata-se da divulgação de uma pesquisa qualitativa, exploratória, bibliográfica e documental realizada em fontes primárias e secundárias, além do próprio filme Caiçara. Procurou-se desse modo articular a história da lepra com as pesquisas sobre feminismo.

\section{A Companhia Vera Cruz e o Filme Caiçara}

O filme Caiçara foi a primeira produção da extinta Companhia Cinematográfica Vera Cruz. A Vera Cruz foi uma empresa criada em 1949 no município de São Bernardo do Campo (SP) e teve suas atividades de produção cinematográfica interrompida depois de cinco anos funcionamento.

A Vera Cruz é considerada o primeiro estúdio com formato profissional e industrial instalado no Brasil e a terceira companhia cinematográfica do país. Antes existiram as cariocas Cinédia, antiga Cinearte, e Atlântida.

Entre 1949 e 1954 (Cf. Maciel, 2013) a Vera Cruz produziu 18 filmes (Cf. Monteiro \& Otre, 2008), de curta, média e longa metragem, além de alguns documentários. A produção que obteve maior sucesso junto ao público nacional e estrangeiro foi o longa-metragem $O$ Cangaceiro (1953), que foi premiado no festival de Cannes no ano de 1953 (O Cangaceiro, 1953, Direção de Lima Barreto, 105 min.).

A companhia tinha por filosofia a instauração de uma produção brasileira de padrão internacional. Tal pretensão expressa bem a ambição do projeto e de seus idealizadores. Teve de fato, diversas influências estrangeiras tanto em seu maquinário, quanto na mão-de-obra. Tendo em vista o mercado nacional propício para o empreendimento, o empresário italiano Franco Zampari em conjunto ao também empresário brasileiro Francisco Antônio Paulo Matarazzo Sobrinho (mais conhecido como Ciccillo Matarazzo), fundaram em 1949 a companhia, erguida no município de São José dos Campos, na região do ABC paulista, em uma área onde antes havia uma granja de propriedade de Ciccilo Matarazzo (Cf. Maciel, 2013).

Com sua extensa área, tomada por estúdios, camarins e refeitórios, o parque cinematográfico visava à produção de filmes em série, em escala industrial, contribuindo para a industrialização das telonas no Brasil. A Vera Cruz procurou renegar as comédias populares da década de 1940, as chanchadas, e apostou em dramas mais aprimorados como Caiçara e $O$ 
Cangaceiro (de 1953). A ideia era que a Vera Cruz fosse uma Hollywood Brasileira, porém uma gestão controversa, falhas administrativas, concorrência desleal dos filmes e produtoras estrangeiros e, principalmente, o lucro exorbitante das empresas distribuidoras que funcionavam como intermediárias entre o público e os produtores de filmes levaram a Vera Cruz a falência (Cf. Malafaia, 2012). Havia poucas distribuidoras na época e elas lucravam mais como atravessadoras do que as próprias empresas de produção de filmes, no caso, aqui abordado a Vera Cruz.

A idéia era utilizar os profissionais, elencos e estúdios da Vera Cruz, com projetos de baixo custo e sem os compromissos de distribuição com a Columbia Pictures, que havia ajudado a quebra da Cia. (Vera Cruz) e ficado com os direitos de comercialização internacional de O Cangaceiro. Como é sábio o filme rendeu para a Columbia milhões de dólares em todo o mundo, dinheiro que se tivesse retornado à Vera Cruz teria sido o suficiente para sanear integralmente a companhia e dar-lhe a sobrevida tão almejada (Ruiz, 2003, p.40).

A Vera Cruz surge num contexto de efervescência cultural paulista. Um momento de inúmeras inaugurações de teatros e museus, como, por exemplo, o Museu de Arte de São Paulo (MASP) em 1947 e o Teatro Brasileiro de Comédia (TBC) em 1948. A cidade de São Paulo passava por um momento de desenvolvimento acelerado e em detrimento disso, a cultura abrangia a cidade com maior pulsão que em outras capitais pelo país. Todavia, a cultura também chegava até outros jovens centros urbanos, como é o caso da capital mineira Belo Horizonte com a inauguração do famoso Teatro Izabela Hendrix (1941).

A partir da inspiração europeia, começa-se a construção de uma identidade brasileira no cinema. Os artistas se dão conta de que, mais que produzir filmes, o cinema deveria ter um papel social. A Vera Cruz teve muita importância na identidade brasileira pelos brasileiros, com o lançamento do premiado filme $O$ Cangaceiro $^{2}$ que inaugurou o gênero cangaço no país (Cf. Miucci, 2013). Até então a realidade nacional não era explorada e exibida ao grande público. Apesar das diversas críticas recebidas devido a incorporação de características consideradas estrangeirismo, o filme $O$ Cangaceiro logrou êxito e contribuiu para a promoção da companhia.

Do planalto abençoado para as telas do mundo era o lema da Companhia Cinematográfica Vera Cruz, inclusive estampado nos cartazes de divulgação dos filmes que foram produzidos. Apesar de almejar a produção do cinema genuinamente brasileiro e sua perpetuação e consagração para o resto do mundo, a companhia possuía um extenso número de estrangeiros em seu quadro de funcionários. A utilização de equipamentos e pessoal 
(CC BY 4.0) | ISSN 2525-3409 | DOI: http://dx.doi.org/10.33448/rsd-v9i11.11268

técnico estrangeiro ocasionou diversos desconfortos no decorrer de suas produções, quer pela exacerbada burocracia na entrada dos equipamentos no Brasil, quer pelas afrontas entre os profissionais nacionais e os alóctones. Essa constatação; a saber: estrangeiros fazendo filmes brasileiros, foi alvo de críticas na época. A justificativa dos fundadores da Vera Cruz era que o Brasil não dispunha de quadros técnicos em número e qualidade suficientes para um projeto do tamanho que a companhia estava empreendendo.

Grandes nomes do cinema, do teatro e da televisão brasileiros, como Mazzaropi, Dercy Gonçalves, Grande Otelo, Tônia Carrero, Anselmo Duarte, Marisa Prado e Renato Consorte foram revelados e projetados pela Companhia Cinematográfica Vera Cruz, assim também como a atriz Eliane Lage, que encenou a personagem principal do filme Caiçara.

A produção cinematográfica Caiçara, dirigida pelo diretor italiano Adolfo Celi foi rodada no período de março de 1950 a setembro do mesmo ano. Foi lançada em $1^{\circ}$ de novembro de 1950 no Cine Marabá, atual Playarte Marabá, e inaugurou os trabalhos da Companhia e da estreante Eliane. A seguir anúncio comercial do filme no jornal Cine Repórter (Cf. Maciel, 2013).

Figura 1 - Anúncio do filme Caiçara - Jornal Cine Repórter.

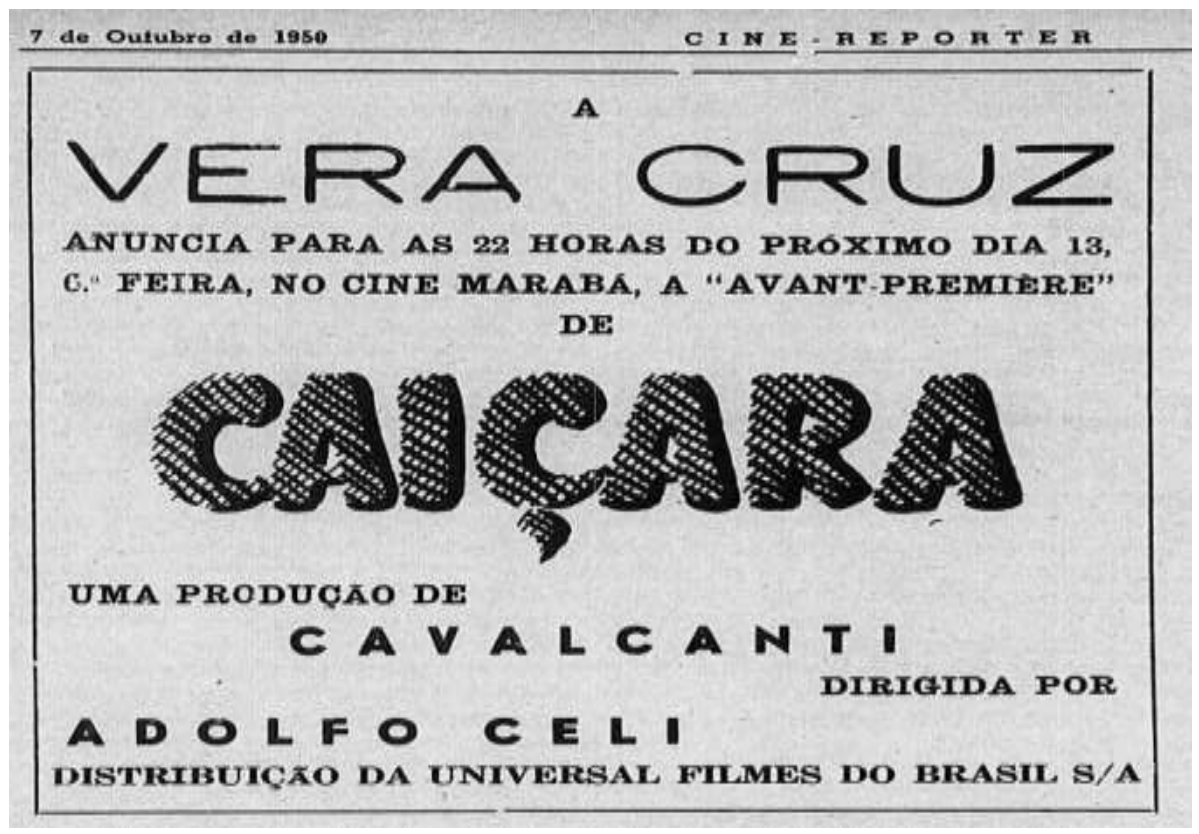

Fonte: Jornal Cine Repórter (07/10/1950).

O livro de Júlio Simões traz a reprodução de cartazes de época de lançamento do filme Caiçara (Simões, 2008, p. 92). 
Research, Society and Development, v. 9, n. 11, e100291111268, 2020

(CC BY 4.0) | ISSN 2525-3409 | DOI: http://dx.doi.org/10.33448/rsd-v9i11.11268

Figura 2 - Anúncio do filme Caiçara - Jornal Estado de São Paulo.

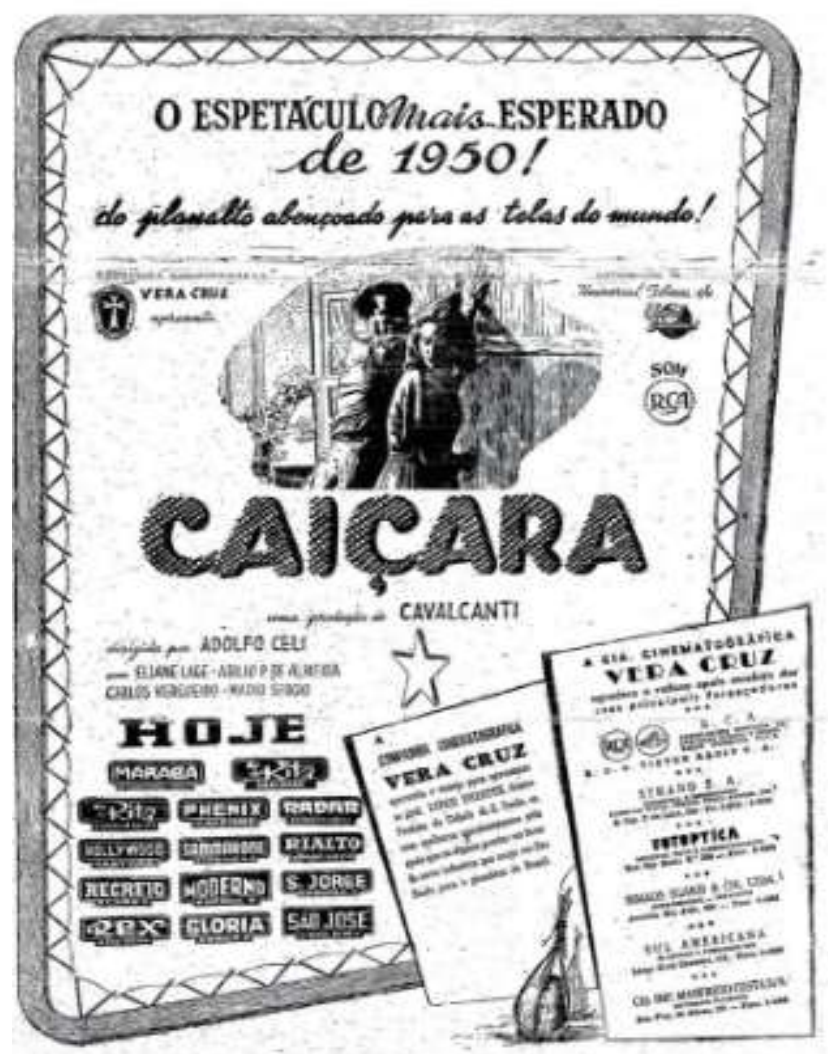

Primeiro filme produzido pela paulista Vera Cruz, Caiçara foi lançado em 12 cinemas da rede de Paulo Barreto de Sá Pinto. 10 Estado de S.Paulo - 1 de novembro de 1950)

Fonte: Simões (2008, p. 92).

Figura 3 - Anúncio do filme Caiçara - Jornal Estado de São Paulo.

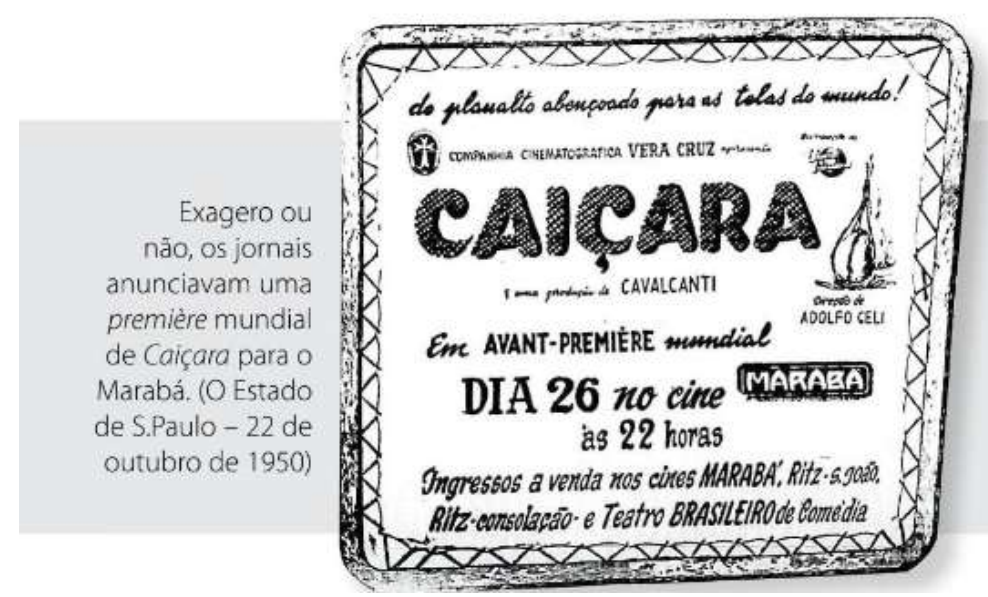

Fonte: Simões (2008, p. 92). 
Figura 4 - Cartaz de Cinema do filme Caiçara - 1950.

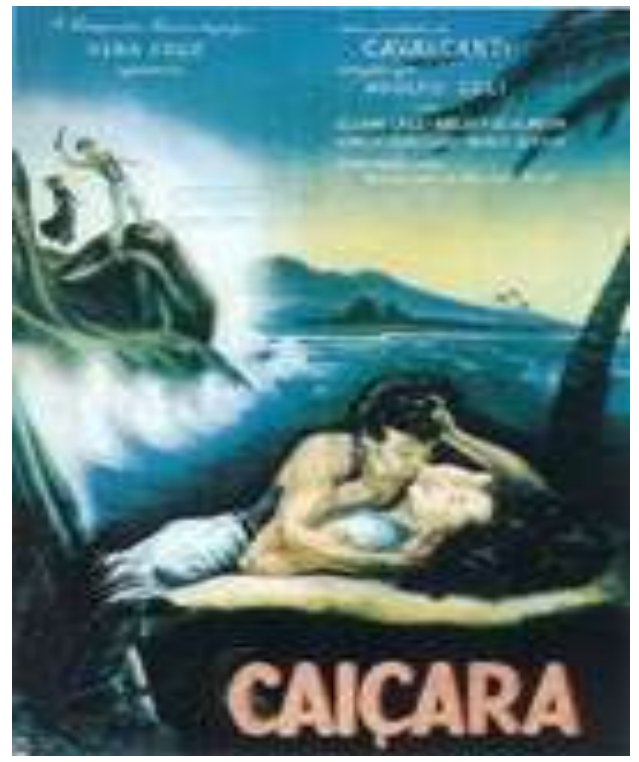

Fonte: Martinelli (2002).

Rodeada por inúmeros problemas, a produção de Caiçara custou aos empresários uma quantia de CR\$ 6.864.120,50 (seis milhões, oitocentos e sessenta e quatro mil e cento e vinte cruzeiros e cinquenta centavos) bem acima do orçamento inicial (Catani, 2018, p. 450). Também não teve o sucesso esperado pela companhia. A julgar pelos dados disponíveis o filme resultou em prejuízo para a Vera Cruz.

Para se ter uma idéia do rendimento dos filmes, o relatório "Resumo das Rendas" nos dá uma amostragem de cada filme produzido pela Vera Cruz. Caiçara (Celi, 1950), por exemplo, rendeu Cr\$ 2.394.781, 30 durante cinco anos em cartaz; Terra é sempre terra (Payne, 1951), quatro anos e nove meses em cartaz, rendeu Cr\$1.337.686, 60; Angela (Payne, 1951) quatro anos e cinco meses em cartaz, rendeu Cr\$1.644.939, 80.

Já o gênero de comédias populares - estreladas pelo comediante Amâncio Mazaroppi -, trouxe para a Vera Cruz rendas maiores e em prazos mais curtos. $\mathrm{O}$ filme Candinho (Almeida, 1952/53) durante dois anos em cartaz, rendeu Cr\$3.355.643, 70, A Família Lero Lero (Pieralisi, 1953) em dois anos e quatro meses em cartaz, rendeu Cr\$ 1.921.095, 20. Liderando as rendas viria o Cangaceiro (Barreto, 1952) que durante dois anos e três meses havia rendido a cifra de Cr\$10.561.327, 20. Outro recorde de bilheteria seria o épico Sinhá Moça (Payne, 1952/53) Cr\$ 6.744.783, 90 durante dois anos e oito meses em cartaz. Havia também os grandes fracassos de bilheteria, como o filme Na senda do crime (Cerri, 1953), que durante um ano e nove meses havia rendido apenas Cr\$261.535, 70 (Maciel, 2008, p. 87-88, grifo nosso).

No entanto, embora tenha recebido diversas críticas, quando Caiçara foi exibido no Festival de Cannes em 1951 foi comparado ao filme italiano Stromboli ${ }^{3}$ (1950, Rosselini) o que foi considerado na época positivo, já que se tratava da primeira produção da Vera Cruz. 
Apesar das dificuldades a produção alcançou espectadores que ainda desconheciam ou não haviam tido contato com o cinema no Brasil. Entre eles o próprio Mário Sérgio, o marinheiro Alberto, uma das estrelas estreantes do filme Caiçara, e nos anos seguintes um galã do cinema brasileiro, foi um desses atingidos pelo cinema veracruzano ${ }^{4}$.

Descoberto num bar, em Santos, nas vésperas da filmagem de Caiçara. Fazia um bruto calor. O rapaz caminhara muito pela praia do Gonzaga ao Zé Menino. Resolveu tomar qualquer coisa gelada num bar. Entrou, por acaso, no primeiro que encontrou. Pediu a bebida. Enquanto esperava, viu que era observado por três indivíduos, que também estavam postados ali, no bar (...) "Você não quer fazer um teste para o cinema rapaz? (....) Mário Sérgio jamais em sua vida pensara em cinema. Confessa atualmente, meio acanhado, que Caiçara ... foi o primeiro filme brasileiro a que assistiu. Não gostava de cinema (...) (Cf.Bonventti, 2015).

O filme Caiçara foi distribuído pela Universal do Brasil S.A. e recebeu o prêmio de melhor filme Brasileiro no Festival de Punta del Este (Uruguai), em 1951; melhor produtor para Alberto Cavalcanti no prêmio Governador do Estado de São Paulo, em 1952; melhor atriz para a protagonista Eliane Lage e o prêmio de melhor atriz coadjuvante do ano de 1950 pela Associação Brasileira de Cronistas Cinematográficos do Rio de Janeiro para Maria Joaquina da Rocha, que interpretou a personagem Sinhá Felicidade, que até então era catadora de papel e não conhecia a arte do cinema.

Após a produção do filme Caiçara, a companhia produziu mais 17 filmes, entre curtas e longas-metragens, sucessos e fracassos. O grande complexo de estúdios e camarins, que tinha por objetivo produzir filmes em escala industrial, com qualidade técnica internacional e uma preocupação com sua linguagem destinada ao público, encerrou seus trabalhos em regime de falência em 1954, devido aos fatores já apontados (Cf. Calllegari \& Goergino, 2003).

A história da Vera Cruz tornou-se um capítulo da história do cinema nacional. Muitos estudiosos falam em um legado da empresa para o Brasil. Sua experiência inspirou a criação da Embrafilme (1969 - 1990) e imprimiu mais qualidade e profissionalismo no cinema nacional.

Após sua falência em 1954, o espaço físico de suas instalações, atualmente conhecido com Estúdios e Pavilhão Vera Cruz, a antiga "fábrica de filmes", passou por diversas utilizações, outras empresas de cinema e televisão o utilizaram, como a Brasil Filmes (1955 a 1959), além de outros produtores independentes. Em 1972, o local foi fechado e três anos depois teve um dos seus prédios demolidos. Em 1975, o local foi adquirido pela Prefeitura de 
Research, Society and Development, v. 9, n. 11, e100291111268, 2020

(CC BY 4.0) | ISSN 2525-3409 | DOI: http://dx.doi.org/10.33448/rsd-v9i11.11268

São Bernardo do Campo (SP) e foi tombado como patrimônio histórico municipal em 1987. Nas décadas de 1980 e 1990 seu espaço físico foi utilizado como espaço para convenções e feiras. Novas tentativas de fazê-lo reativar novamente foram realizadas em 1991, 1998 e 2015.

Em 2017, a Prefeitura de São Bernardo do Campo (SP) reassumiu o local que tem sido utilizado predominantemente por emissoras de televisão para filmagem de programas específicos. Apresentadores como Luciano Huck, Gugu Liberato e Xuxa Meneguel já filmaram no local, além de outros nomes famosos já tiveram passagem no Vera Cruz, como a modelo Gisele Bündchen, o jogador de futebol Neymar e músico Carlinhos Brown. ${ }^{5}$

\section{A História no Filme}

O primeiro filme da Companhia Vera Cruz é um drama que narra a história da jovem Marina que vive num preventório paulista. Um preventório (Cf. Curi, 2006) era o nome dado aos orfanatos específicos para crianças saudáveis separadas compulsoriamente pelo Estado dos pais leprosos que estavam sobre isolamento sanitário obrigatório. Marina era o que se chamou na época de "Órfãos de Pais Vivos" " numa triste e célebre expressão. Ao todo no Brasil existiram 36 preventórios no auge do isolamento dos leprosos no País, inaugurados entre 1927 a 1952.

O filme não informa o nome exato do preventório onde Marina se encontrava. Numa das primeiras cenas uma placa anuncia que as jovens estavam no Asilo Santa Clara. Este nome é fictício. Sabemos que o Estado de São Paulo na época teve dois preventórios: Santa Terezinha e Jacareí. No filme o preventório onde Marina está internada é um local aprazível, ajardinado e muito bonito. Contudo, alguns estudos sobre os preventórios em São Paulo informam que a instituição não era a maravilha que o filme Caiçara faz transparecer, conforme depoimento recolhido pela historiadora Yara Nogueira Monteiro.

"Lá era muito pobre, a alimentação era muito pobre. (...) Nós não tínhamos esporte, recreação nada. Depois que eu saí é que começou a melhorar um pouco, mas enquanto eu estive lá não tinha nada. (...) No Natal a gente ganhava brinquedo. E a gente comia frango. Também era só no Natal. Ia um pessoal de São Paulo, umas senhoras, acho que alguma associação, e eles levavam brinquedos para nós... Todo ano." (ANA, 1992, apud: Monteiro, 1998, p.18).

O filme Caiçara teve como principais artistas Eliane Lage e Mário Sergio até então desconhecidos pelo público. O enredo possuiu como cenário o litoral paulista, mais 
Research, Society and Development, v. 9, n. 11, e100291111268, 2020

(CC BY 4.0) | ISSN 2525-3409 | DOI: http://dx.doi.org/10.33448/rsd-v9i11.11268

precisamente em Ilhabela, munícipio próximo à cidade litorânea de Santos, onde se localiza um dos maiores e mais conhecidos portos marítimos comerciais brasileiros. A seguir duas sinopses de referência do enredo do filme.

Caiçara vai mostrar, de maneira inequívoca, uma forma muito clara de se conceber a realidade social e o imaginário que nela se engendra.

A trama de Caiçara mistura, de uma maneira singela, um melodrama afetivo e alguns toques de suspense policial, envolvendo dois assassinatos. Todo o eixo do enredo passa pela relação entre Zé Amaro ${ }^{7}$ e Marina, ele um "empresário" dono de um pequeno estaleiro na Ilha Verde, e ela, uma moça que teve de ir cedo para um orfanato, pois seus pais eram doentes de lepra e viviam reclusos em um dispensário ${ }^{8}$. Para sair do orfanato ela aceita casar-se com Zé Amaro, sem ter muita ideia de onde vai morar e com quem, pois, na sua opinião, qualquer lugar seria melhor do que aquele no qual se encontrava. A trama se desdobra a partir do momento em que Zé Amaro se cansa da frieza da esposa e vai para Santos "cair na farra" nos bordéis.

Aqui se constitui o momento de inflexão fundamental do filme, pois, a partir deste momento, a história vai mudar de rumo e mergulhar nas "tramas" do amor e da morte. Na sua ausência, Marina será assediada pelo sócio de Zé Amaro, o Mané, que, tomado por ciúmes e pelas recusas incessantes de Marina, termina por assassiná-lo em alto mar, para tentar definitivamente ficar com ela. Durante aquele período, Marina recebe apoio da ex-sogra de seu marido (Sinhá Felicidade), que constantemente o acusa de ter assassinado sua filha. Mostrando-a como detentora de um poder advindo da umbanda, o filme associa a morte de Zé Amaro a uma mandiga que ela fez com um boneco onde se colocaram fios de seus cabelos recolhidos de seu pente em uma visita. Ela coloca o boneco (uma espécie de vudu) em baixo d'água, pouco antes de Zé Amaro, morrer afogado. Por fim Marina recusa as propostas de Manoel e acaba por iniciar um romance com Alberto, marinheiro que havia conhecido Zé Amaro em Santos, e que acaba se radicando na ilha. Manoel, com ciúmes, acaba brigando com Alberto e matando o neto de Sinhá Felicidade, a ex-sogra de Zé Amaro, que o havia visto brigando com Alberto e incomodando Marina, por quem o garoto tinha muita afeição. O filme termina de uma forma um pouco bisonha, ao consolidar o romance de Marina e Alberto na porta do cemitério, onde será enterrado o corpo do garoto, com as bênçãos de sua avó (Menezes, 2000, p.313).

No site da Cinemateca Brasileira a descrição do filme é a seguinte:

Marina é filha de leprosos e vive num asilo, de onde é levada por Zé Amaro, um viúvo construtor de barcos em Ilhabela, onde passam a morar depois do casamento. Sua nova vida só lhe traz decepções: o marido vive de bebedeiras e ela é cobiçada pelos homens do lugar. Seu único conforto é o menino Chico, cuja avó, dona Felicidade, adepta a bruxarias, torna-se sua conselheira. Dona Felicidade, ex-sogra de Zé Amaro, diz que este matara sua filha. $\mathrm{O}$ drama do casal se intensifica quando Marina passa a ser perseguida por Manoel, sócio de seu marido, que tenta conquistá-la à força. No teste de um novo barco, Zé Amaro é derrubado propositalmente no mar por Manoel. A situação muda após a morte de Zé Amaro e a chegada de Alberto, um marinheiro que se apaixona por Marina, e por ela é correspondido. Enciumado, Manoel ameaça 
Research, Society and Development, v. 9, n. 11, e100291111268, 2020

(CC BY 4.0) | ISSN 2525-3409 | DOI: http://dx.doi.org/10.33448/rsd-v9i11.11268

Marina com o segredo dos seus pais, que morreram de lepra. Ciente da situação, Alberto dá uma surra em Manoel. Chico, que assistira à luta, é perseguido por Manoel e morto. Revoltada com a morte de Chico, a população persegue Manoel, que morre durante a fuga. Após a tragédia de Chico e a Morte de Manoel, Marina e Alberto seguem suas vidas juntos (Cf. Cinemateca Brasileira - 1950 - Registro em 27/09/1950).

Para o estudioso Adilson Ruiz que publicou trabalho sobre a Vera Cruz e seus filmes, ele emite a seguinte análise do filme Caiçara:

Os três filmes (refere-se a Caiçara, Terra é sempre terra e Ângela) são dramas ambientados em diferentes locais, mas tratam de conflitos muito semelhantes. Em Caiçara e Terra é sempre terra muda o cenário, mas a trama é praticamente a mesma: o triângulo amoroso formado por uma mulher jovem, bonita e sofredora, que vive um casamento infeliz, por conveniência e sem amor; uma marido mais velho, dominador e grosseiro; e um homem jovem e bonito, que se torna amante da mulher e com a qual forma o casal apaixonado da trama. Ao final o marido morre, librando a mulher para viver a vida que ela quiser, com ou sem o amante. Os diferentes cenários - a ilha em Caiçara, e a fazenda de café em Terra é sempre terra não integram o enredo. A ambientação serve para dar uma "cor" local ao filme, com a inserção de cenas de festas, danças e cantorias típicas dessas comunidades (...). É interessante observar que nesses três filmes da Vera Cruz, as mulheres têm aparência frágil, mas são fortes e acabam construindo seu destino. E os personagens masculinos têm sempre algum vício que causa a infelicidade de seus relacionamentos amorosos e arruína suas vidas. Em Caiçara, o marido é bêbado e mulherengo, e acaba perdendo a mulher (e a vida, pois termina assassinado) (Ruiz, 2003, pp. 22-23).

A história da Companhia Cinematográfica Vera Cruz reflete a história do cinema nacional. $\mathrm{O}$ grande sonho do cinema brasileiro profissional torna-se realidade com a produção e lançamento do filme Caiçara, primeiro filme da Vera Cruz. Tratava-se de uma história de amor universal, do amor romântico do casal que sofre agruras até finalmente conseguirem estabelecer as condições para viverem seu grande enlace amoroso. História de amor que se desenrola numa típica moldura brasileira. Embora não tenha feito o sucesso de bilheteria esperado, a produção cinematográfica incrementou os trabalhos do cinema nacional. Para os críticos da época o Caiçara seria "apenas uma melodramática história de leprosos" (Maciel, 2008, p.116).

Para encabeçar o elenco de Caiçara, dois desconhecidos: Eliane Lage, considerada na época uma lindíssima e enigmática mulher, e o futuro galã dos estúdios, Mário Sérgio. Assim que os dois foram escolhidos para os papéis principais iniciaram as filmagens e publicidade do filme na impressa brasileira da época. Essa estratégia de propagandear o filme durante sua 
Research, Society and Development, v. 9, n. 11, e100291111268, 2020

(CC BY 4.0) | ISSN 2525-3409 | DOI: http://dx.doi.org/10.33448/rsd-v9i11.11268

produção foi uma inovação da Companhia Vera Cruz a época. A ideia era que quando o filme estivesse pronto o público já estivesse informado e desejoso de ver e apreciar a película.

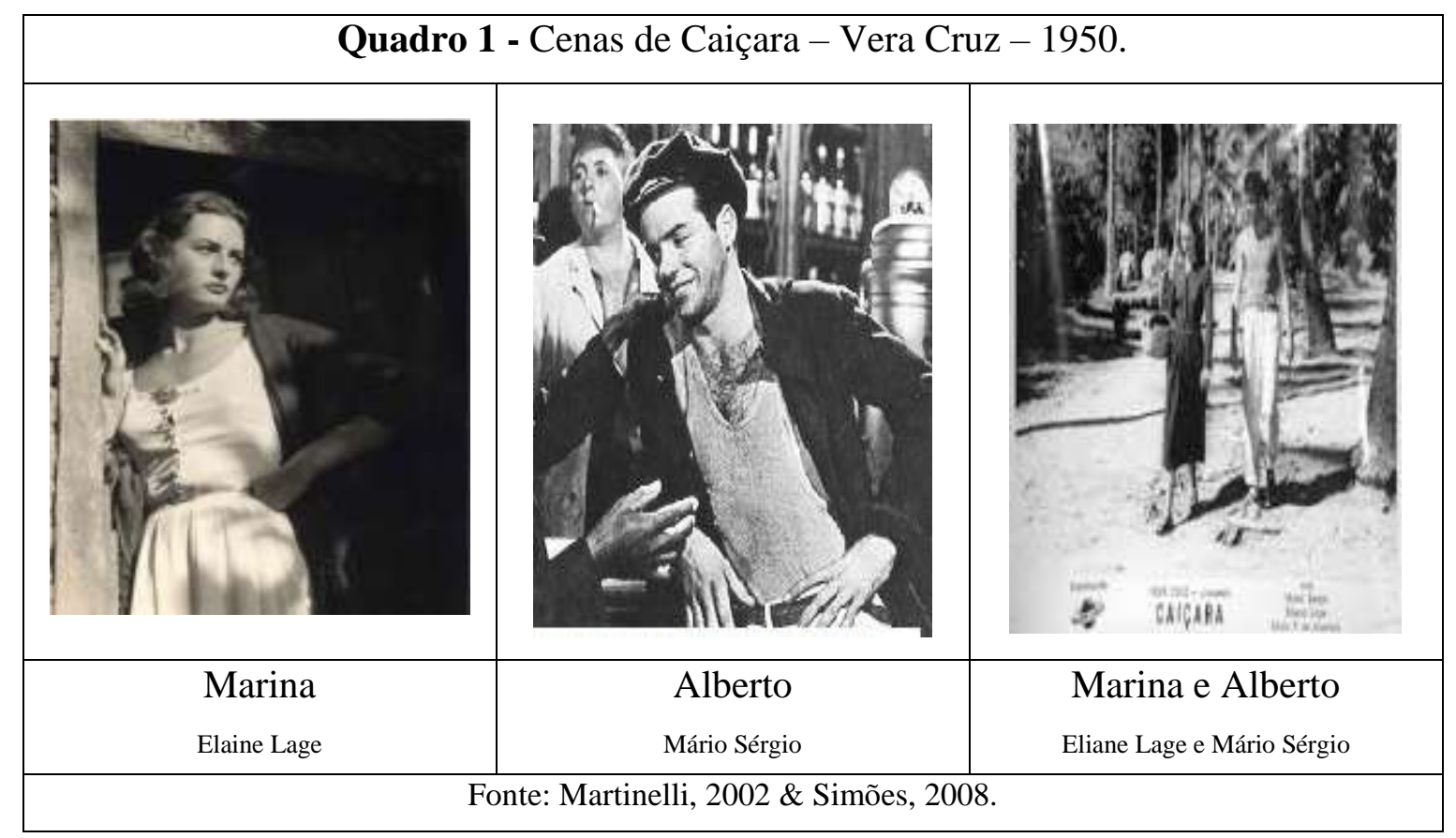

Logo no início do filme, após a apresentação panoramicamente do dito Asilo Santa Clara, ocorre uma cena importante e representativa do mundo da lepra no Brasil da Era do Isolamento de 1924 a $1986^{9}$ (Cf. Curi, 2019). Trata-se de um diálogo entre Marina e suas quatro companheiras de preventório. Elas estavam conversando na área externa enquanto Zé Amaro, o futuro esposo de Marina, encontra-se na sala da direção conversando com a diretora do preventório, cujo nome não é informado e é interpretada pela atriz Zilda Barbosa, e com o médico do orfanato, personagem do ator Venéleo Fornasari. O diálogo dá urdidura a história que se desenrolará depois ${ }^{10}$ :

\section{Quadro 2 - Diálogos de Caiçara - Vera Cruz - 1950}

Diretora do Preventório: Muito bem. Os papéis estão prontos. Tomamos todas as informações de praxe. Agora só falta marcar a data (do casamento de Marina e Zé Amaro).

Zé Amaro: Para mim quanto antes melhor. Estou com muito trabalho na ilha e não posso perder mais tempo (refere-se ao seu estaleiro em Ilhabela no Estado de São Paulo).

Diretora do Preventório: Mas não esqueça que o senhor vai casar com uma moça que sempre viveu separada dos pais. E, que, por mais que se faça, tem um certo medo da doença deles. O doutor aqui poderá lhe explicar melhor.

Médico do Preventório: Sim. Num caso desses é melhor não ter pressa. Eu sei como são essas meninas. Se ofendem por qualquer coisa. Não há perigo nenhum, já disse que essa doença não é hereditária. Mas, o senhor 
sabe é uma doença, que naturalmente assusta.

*** do lado de fora Marina e suas companheiras de orfanato conversam.

$\mathbf{1}^{a} \mathbf{M o c ̧ a}^{11}$ :Olhe está falando com o médico.

$2^{a}$ Moça $^{12}$ : Conversa demorada.

$3^{a}$ Moça (está sentada junto com Marina) ${ }^{13}$ : Vai ver que ele mudou de ideia.

$1^{a}$ Moça: Porque?

$3^{a}$ Moça: Hum.

$2^{a}$ Moça: No mínimo conversou com os parentes e agora deu medo.

$3^{a}$ Moça: Antes agora do que depois. Vocês se lembram da Ondina?

$4^{a}$ Moça $^{14}$ : E.... Casou toda contente. Mal passaram dois meses e o marido sumiu.

Marina: Marido sumiu porque não prestava.

$2^{a}$ Moça: E você conhece o seu? Deixe disso Marina falou com ele só duas vezes.

$4^{a}$ Moça: Se você não topava.

Marina: Eu quero é sair daqui (refere-se ao Preventório). O mais é da minha conta.

Médico do Preventório: Marina (chama o médico Marina para ela ir até a sala da direção).

Zé Amaro: Fique sossegada tomarei bem conta dela (diz Zé Amaro a diretora enquanto aguardam o retorno do médico com Marina que foi chamá-la no pátio do Preventório).

*** O médico e Marina chegam à sala da direção do preventório.

Diretora do Preventório: Minha filha está tudo resolvido. Conversei muito com o senhor José Amaro e tudo vai dar certo. Ele compreendeu muito bem a sua situação e você não precisa ter medo de nada.

Marina: Eu não tenho medo.

Diretora do Preventório: Eu já sabia. Porém a minha obrigação era explicar tudo. Agora só falta marcar o dia.

Zé Amaro: se for no sábado, ainda dava tempo de pegar a lancha (para o município de Ilhabela onde residia e trabalhava Zé Amaro).

Marina: o senhor é quem sabe (diz Marina para Zé Amaro).

Fonte: Filme Caiçara - 1950 - Elaboração dos autores.

No diálogo transcrito pode-se verificar duas situações que foram costumeiras no mundo da lepra no Brasil. Primeiro, o caso de Ondina que foi abandonada pós-altar pelo marido, dado seu passado ligado a lepra. Segundo, o caso de Marina que muito jovem, casase com um homem bem mais velho, um viúvo quarentão, para escapar da vida no preventório. Uma vida que ao que tudo indica não era boa já que todas as pessoas ali naquela instituição eram órfãs e desamparadas socialmente. Afinal a busca por casamento, como no caso de 
Ondina e Marina, evidencia que a vida no preventório tinha seus desconfortos. Numa acepção mais atual; as moças do preventório eram vulneráveis.

A história de Marina é narrada no filme desde a infância até o momento que se encontra com seu "grande amor" o marinheiro Alberto, interpretado por Mário Sérgio. Os dois então passaram a viver um romance e ao término do filme estão juntos o que faz transparecer para o espectador que Marina realizou-se no amor e finalizou-se suas grandes inquietações e sofrimentos.

Marina foi retirada do preventório por um homem viúvo chamado Zé Amaro, modesto construtor de barcos em Ilhabela, município do Estado de São Paulo. O casamento era uma forma legal e incentivada para deixar os orfanatos na época. Ela casa-se com Zé Amaro após uma negociação que ele empreende com a diretora do preventório e consentida por Marina. Logo após o término da cerimônia do casamento, que ocorreu num sábado, Marina vai morar com o ilhéu em sua casa no litoral paulista. O casamento, com o passar do tempo, torna a vida da protagonista cada vez mais melancólica, tediosa e violenta, devido ao constante conflito com seu marido alcoólatra, dominador e relapso com os negócios.

Assim que Marina chega à ilha logo se torna notícia e alvo de vários comentários por sua beleza jovial e sedutora. $\mathrm{O}$ filme tem várias cenas com os habitantes locais admirando sua beleza na sua chegada. É apresentada por seu marido a diversas pessoas da comunidade de Ilhabela com as quais passaria a ter convívio a partir de então. Com poucos dias habitando a ilha, conhece uma criança, o menino Chico, e sua avó, uma senhora chamada Sinhá Felicidade, que aponta os perigos do convívio com Zé Amaro. A senhora foi a sogra de Zé Amaro, de seu primeiro casamento, e o acusa como responsável pela morte de sua filha, a Bentinha.

As condições materiais da vida cotidiana de Marina são muito simples e modestas. Uma vida caiçara, no dizer do linguajar da região, uma vida modesta, sem luxos.

Zé Amaro viaja regularmente a trabalho e Marina tem muitos períodos de solidão. Foi durante as ausências do marido que o sócio de Zé Amaro chamado Manuel resolve cortejar, galantear e, posteriormente, até assediar Marina. Manuel se apaixona pela beleza de Marina desde o primeiro encontro. Esta paixão é o início de muitos dos conflitos que irão ocorrer no decorrer do filme. Marina não corresponde as investidas de Manuel que cada vez ficam mais incisivas e até violentas e ameaçadoras.

Uma inflexão interessante da história é a relação Manuel/Marina/lepra. Manuel se declara apaixonado e propõe a Marina que se case com ele. Ele revela seu amor. A lepra, ele sabia do passado leprótico de Marina, não o impede de buscar o seu amor. Contudo, quando 
Research, Society and Development, v. 9, n. 11, e100291111268, 2020

(CC BY 4.0) | ISSN 2525-3409 | DOI: http://dx.doi.org/10.33448/rsd-v9i11.11268

percebe que não terá sucesso e não será correspondido ele evoca a lepra como forma de ameaçar, desestabilizar e atacar Marina. O fato de Marina ficar transtornada com o passado leprótico é uma das evidências históricas presente no filme de que a lepra representava naquela época algo constrangedor e que poderia, a julgar pelo destino de Ondina, resultar em dissoluções de relacionamentos, matrimônios e laços sociais.

O elenco do filme Caiçara é uma história a parte. Sem estrelas de envergadura e muitos novatos, contou inclusive com habitantes locais de Ilhabela. $\mathrm{O}$ filme tem um pouco de etnografia que ainda não foi estudado. As noitadas de cantorias improvisadas, os chamados repentistas, são uma forma inusitadas que o diretor do filme encontrou de amarrar e costurar o enredo. Na época o grande meio de circulação de notícias era o rádio e Ilhabela como lugar pobre, tudo indica, não era dotada de fartura desse artefato. Durante o filme o rádio aparece apenas uma vez, na cena do bar, durante a transmissão de uma partida futebolística (do Juventus). Ou seja, as cantorias funcionavam como um meio da comunidade falar de si própria, dos seus acontecimentos, seus problemas e assuntos que eram o foco das atenções. A tabela a seguir lista o elenco do filme:

\begin{tabular}{|c|c|c|}
\hline \multicolumn{3}{|c|}{ Quadro 3 - Elenco - Filme - Caiçara - $1950^{15}$} \\
\hline Nome do(a) personagem & Nome do Ator/Atriz & Papel \\
\hline Marina & Eliane Lage & Protagonista. \\
\hline $\begin{array}{l}\text { Zé Amaro } \\
\text { (José Amaro de Campos) }\end{array}$ & Abílio Pereira de Almeida & Esposo de Marina. \\
\hline Alberto & Mário Sérgio & $\begin{array}{l}\text { Marinheiro, grande amor romântico } \\
\text { de Marina. }\end{array}$ \\
\hline Ondina & ---- & $\begin{array}{l}\text { Colega de Preventório que foi } \\
\text { abandonada pelo marido (pós-altar) } \\
\text { devido ao medo e ao preconceito } \\
\text { com relação a seu passado ligado a } \\
\text { lepra. }\end{array}$ \\
\hline Manuel da Silva & Carlos Vergueiro & $\begin{array}{l}\text { Sócio de Zé Amaro e algoz de } \\
\text { Marina. }\end{array}$ \\
\hline Bentinha & - & $\begin{array}{l}\text { Primeira esposa de Zé Amaro. Filha } \\
\text { de Sinhá Felicidade. }\end{array}$ \\
\hline Sinhá Felicidade & Maria Joaquina da Rocha & Primeira sogra de Zé Amaro. \\
\hline Chico & Osvaldo Eugênio & $\begin{array}{l}\text { Neto de Sinhá Felicidade. Protetor } \\
\text { de Marina. }\end{array}$ \\
\hline
\end{tabular}


Research, Society and Development, v. 9, n. 11, e100291111268, 2020

(CC BY 4.0) | ISSN 2525-3409 | DOI: http://dx.doi.org/10.33448/rsd-v9i11.11268

\begin{tabular}{|c|c|c|}
\hline Não informado & Zilda Barbosa & Diretora do Preventório. \\
\hline Não informado & Venério Fornazari & Médico do Preventório. \\
\hline Não informado & A.C. Carvalho & Fotógrafo alemão. \\
\hline Kitaro & Tetsamura Arima & $\begin{array}{l}\text { Funcionário do estaleiro de Zé } \\
\text { Amaro/Manuel da Silva. }\end{array}$ \\
\hline Tanaka & Akiyoshi Kadobayaschi & $\begin{array}{l}\text { Funcionário do estaleiro de Zé } \\
\text { Amaro/Manuel da Silva. }\end{array}$ \\
\hline Não informado & Antônio Rocha & Preto Velho Marinheiro. \\
\hline Não informado & Pedro Ventura & Piloto do Barco. \\
\hline Olívia & Gaby de Rose & Meretriz do Bordel de Santos. \\
\hline Não informado & Maria Aparecida & Garçonete do Bordel de Santos. \\
\hline $1^{\text {a }}$ Moça - Não informado & Maiza Pereira de Almeida & Colega de Marina no Preventório. \\
\hline $2^{\mathrm{a}}$ Moça - Não informado & Célia Biar & Colega de Marina no Preventório. \\
\hline $3^{\mathrm{a}}$ Moça - Não informado & Eunice Faro & Colega de Marina no Preventório. \\
\hline $4^{\mathrm{a}}$ Moça - Não informado & Cecília Machado & Colega de Marina no Preventório. \\
\hline Não informado & Rubem Bandeira & Empregado do Bar da Ilhabela. \\
\hline Não informado & Carlo Zampari & Tatuador. \\
\hline Zazá & Maria Alice Domingues & Não informado. \\
\hline Genovês & Adolfo Celi (diretor do filme) & Proprietário do engenho de cachaça. \\
\hline Genovesa & Gini Bretani & Esposa do genovês. \\
\hline Não informado. & Ricardo Campos & Delegado de Polícia. \\
\hline Não informado. & Yeyai Mikuti & $\begin{array}{l}\text { Empregada de Marina. Neta de } \\
\text { kitaro. }\end{array}$ \\
\hline Não informado. & Salvador Daqui & Homem da praia. \\
\hline Dona Cecília & Lizzie O. Costa & Moradora de Ilhabela. \\
\hline Herege Parente & -------- & $\begin{array}{l}\text { Médico que cuidou da primeira } \\
\text { esposa de Zé Amaro (Bentinha) na } \\
\text { Santa Casa. }\end{array}$ \\
\hline Zico & Não informado & Morador de Ilhabela. \\
\hline Benedito & Não informado & Morador de Ilhabela. \\
\hline
\end{tabular}


Research, Society and Development, v. 9, n. 11, e100291111268, 2020

(CC BY 4.0) | ISSN 2525-3409 | DOI: http://dx.doi.org/10.33448/rsd-v9i11.11268

Um equívoco bastante recorrente relacionado ao filme Caiçara é com relação ao escritor brasileiro José Mauro de Vasconcelos, autor do clássico infanto-juvenil Meu pé de Laranja Lima, publicado originalmente em 1968. Na década de 1950 José Mauro ainda não era famoso e tentou diversas carreiras até a consagração literária. Ele inclusive trabalhou em diversos filmes da Vera Cruz, mas não em Caiçara. Tanto na ficha disponível no site da Cinemateca Brasileira quanto nos créditos iniciais e finais do filme o nome de José Mauro não aparece. Por ocasião deste estudo foi feita uma verificação cuidadosa e confirmou-se que apenas fontes posteriores, após José Mauro tornar-se reconhecido nacionalmente e internacionalmente, é que informam que ele integrou o elenco de Caiçara. Chamo isso de Equivoco José Mauro de Vasconcelos. Apesar de ser comum essa informação nenhuma fonte de época apoia e escora seu nome no elenco. ${ }^{16}$

No filme a lepra dos pais de Marina é uma ameaça que a assombra, mas nunca se materializa e efetiva. $\mathrm{O}$ diretor do filme estabelece um jogo na construção da história. Marina é uma mulher linda, que poderia se transformar numa horrorosa leprosa. Uma beleza que poderia se degenerar na feiura da lepra. Cenas onde Marina mostra sua sensualidade no espelho ou coloca as mãos no rosto tendem a insinuar para o espectador que Marina teme repentinamente tornar-se uma leprosa. Trauma de sua vida familiar e da infância.

Contudo, a mesma lepra que oprime Marina a redime também. A lepra a levou ao preventório e ao casamento sem amor com Zé Amaro. Quando Manuel, o sócio de Zé Amaro se apaixona por ela, ele não se importa com seu passado leprótico, contudo, quando percebe que não será correspondido tenta inviabilizar seu novo casamento com a revelação da lepra de seus pais e sua potencialidade de também vir a ser uma leprosa. Manuel diz que ela tem lepra no sangue e talvez seja uma leprosa prestes a revelar-se.

Contudo, quando o marinheiro Alberto por ela se apaixona e toma conhecimento do passado de lepra de Marina, ele não a rejeita, como ocorreu com Ondina, nem a chantageia com pedidos e imposições de restrições. Ele a aceita plenamente e revida a ameaça brigando e espancando Manuel. Enfim, é a realização do amor pleno e romântico. Do outro lado Marina também não se mostra leprosa e asquerosa na alma. Ela não se interessa por Manuel, que inclusive, é financeiramente mais rico do que Alberto. A própria Sinhá Felicidade diz a Marina que Manuel é um homem bom, trabalhador, próspero. Ela não busca repetir os erros cometidos com Zé Amaro. Diferente da primeira experiência agora ela busca o amor.

Um amor que o filme mostra como redentor de todos os envolvidos. É interessante observar que Alberto e Zé Amaro se conhecem em Santos, num bordel, momento no qual o casamento Zé Amaro/Marina já era realidade. Zé Amaro termina sua vida errônea assassinado 
pelo sócio Manuel motivado por ciúmes dado a frustração de suas pretensões de se casar com Marina. Já Manuel termina morrendo na cena que em que foge da perseguição da comunidade caiçara quando descobrem que havia assassinado o menino Chico. No decorrer da trama Manuel comete dois homicídios (Zé Amarro e o menino Chico). Por fim Alberto também é redimido pelo amor por Marina, ele deixa de ser marinheiro, radica-se em Ilhabela e ampara Marina. Marina encontra em Alberto o seu par perfeito com quem termina o filme desembaraçada dos seus algozes, inclusive, da lepra.

\section{A Lepra no Filme Caiçara}

A lepra é alvo de diversos estudos nas mais variadas áreas do conhecimento. Da mesma maneira é retratada pelos mais variados segmentos da arte, como na literatura em livros renomados como Tristão e Isolda, uma lenda medieval. Também autores brasileiros como o Visconde de Taunay (Cf. Curi, 2010) no seu livro Inocência (1872) abordam a lepra. Da mesma forma, a condição dos leprosos foi também explorada pela arte do cinema, como na superprodução Ben-Hur (1959), o segundo filme mais bem sucedido da história, e Cruzadas (2005) que conta a história do rei leproso Balduíno IV de Jerusalém. Outro filme que também abordou a questão da lepra na década de 1950 foi Diários de Motocicleta (2004).

A lepra remonta um conjunto de representações negativas que assolou a vida de um sem-número pessoas ao longo da história humana. Tais representações aparecem na produção cinematográfica Caiçara de forma amena e sutil.

Tradicionalmente os estudiosos tem chamado essas representações de estigma. Contudo, essa conceituação certamente precisa ser revista a luz dos estudos mais recentes sobre vulnerabilidade social. O conceito de estigma foi recorrente na sociologia das décadas de 1950 e 1960 e ao longo das últimas décadas foi se tornando cada vez menos utilizado em análises nas Ciências Humanas. Uma possível explicação para abandono do conceito refere-se a sua origem na Biologia o que lhe atribuiria aspectos mais deterministas e menos culturais. Fala-se em estigmas como parte das plantas que recepcionam o pólen e dão as características as novas plantas que virão após a reprodução.

Estigma: o estigma é um rótulo social negativo que identifica pessoas como desviantes, não porque seu comportamento viole normas, mas porque elas têm características pessoais ou sociais que levam outras pessoas a excluí-las. Indivíduos obesos, com defeitos físicos ou desfigurados (sobretudo no rosto) não violaram normas, mas frequentemente são tratados como se o tivessem feito. Esse fato aplica-se também aos que são identificados como homossexuais, doentes mentais ou infectados 
Research, Society and Development, v. 9, n. 11, e100291111268, 2020

(CC BY 4.0) | ISSN 2525-3409 | DOI: http://dx.doi.org/10.33448/rsd-v9i11.11268

pelo vírus da AIDS, ou parentes de alguém que seja um traidor ou assassino que violou normas importantes. O estigma também pode ser aplicado a grupos minoritários, tais como negros, judeus e mulheres, cujo único crime consiste simplesmente em fazer parte de uma categoria social estigmatizada (Johnson, 1997, pp. 93-94).

Contudo, na sociedade humana as características não são imutáveis, fixas ou dadas pela natureza. Elas são sociais e culturais. As mulheres, negros, e deficientes não são discriminados da mesma forma em todas as culturas. $\mathrm{O}$ que alicerça e informa o tratamento negativo, não é a característica do discriminado, mas a cultura. Ademais, nem todas as discriminações sociais repousam sobre características físicas e biológicas. Pobreza, orfandade, discriminações políticas e étnicas (não confundir com raça) baseiam-se em diferenciações sociais e culturais e não biológicas. Os próprios leprosos não foram discriminados da mesma forma durante todas as épocas. Houve variações temporais e geográficas. Existem certas características que lograram produzir certas formas de preconceito, rotulação e discriminação em apenas certas sociedades, como os dalits na Índia, por exemplo, e que não existem em outros lugares.

Enfim a teorização a partir da categoria estigma faz a análise centrar-se na característica e não na cultura. Assim, neste estudo, preferimos adotar a postulação teórica de discriminação social para com os leprosos advinda de rotulações socias, e não mais estigmatização. ${ }^{17}$

Assim, deste modo verifica-se que a lepra no filme Caiçara é um elemento de destaque, mas não central. Ao longo do filme o tema da lepra aparece em 06 (seis) ocasiões/momentos/menções: 
Research, Society and Development, v. 9, n. 11, e100291111268, 2020

(CC BY 4.0) | ISSN 2525-3409 | DOI: http://dx.doi.org/10.33448/rsd-v9i11.11268

\begin{tabular}{|c|c|c|c|}
\hline \multicolumn{4}{|c|}{ Quadro 4 - Menções a lepra no Filme Caiçara de 1950.} \\
\hline $\mathbf{N}^{\mathbf{0}}$ & MOMENTO & SITUAÇÃO & DESCRIÇÃO \\
\hline 01 & $\begin{array}{c}02 \min 08 \mathrm{~s} \\
\left(2^{\prime} 8^{\prime \prime}\right)\end{array}$ & $\begin{array}{l}\text { Início. Diálogo do } \\
\text { casamento no Preventório. }\end{array}$ & $\begin{array}{l}\text { Marina resolve se casar para deixar o } \\
\text { Preventório. A diretora da instituição avisa José } \\
\text { Amaro das questões envolvidas com a lepra. }\end{array}$ \\
\hline 02 & $\begin{array}{l}19 \min 03 \mathrm{~s} \\
\left(19^{\prime} 3^{\prime \prime}\right)\end{array}$ & $\begin{array}{l}\text { Briga do casal Zé Amaro e } \\
\text { Marina. }\end{array}$ & $\begin{array}{l}\text { Após um mês de casamento Zé Amaro reclama } \\
\text { da indiferença da esposa. Ele reclama que ela } \\
\text { nem havia aberto a mala com os presentes de } \\
\text { casamento. Ele então diz: "Diz alguma coisa. } \\
\text { Você fica aí muda. Deu lepra na língua." }\end{array}$ \\
\hline 03 & $\begin{array}{l}43 \min 38 s \\
\left(43^{\prime} 38^{\prime \prime}\right)\end{array}$ & $\begin{array}{l}\text { Zé Amaro bêbado afronta } \\
\text { e desafia seu sócio Manuel }\end{array}$ & $\begin{array}{l}\text { Após uma visita a um amigo que doa várias } \\
\text { garrafas de cachaça a Zé Amaro o casal retorna a } \\
\text { Ilhabela onde Zé Amaro bêbado insulta e ofende } \\
\text { seu sócio Manuel. Zé Amaro diz: "Vamos } \\
\text { (Manuel) dê um beijo nela. Ou será que tem } \\
\text { medo da lepra. Não há perigo. Lepra não passa } \\
\text { pros filhos". }\end{array}$ \\
\hline 04 & $\begin{array}{l}71 \min 51 \mathrm{~s} \\
\left(71^{\prime} 51^{\prime \prime}\right)\end{array}$ & $\begin{array}{l}\text { Ameaça de Manuel a } \\
\text { Marina }\end{array}$ & $\begin{array}{l}\text { Após Manuel saber que Marina resolve-se casar } \\
\text { com o Marinheiro Alberto ele ameaça contar para } \\
\text { o marinheiro o passado de Marina ligado a lepra. } \\
\text { A montagem da cena dá entender que Marina } \\
\text { corre o risco de se transformar numa espécie de } \\
\text { Ondina. }\end{array}$ \\
\hline 05 & $\begin{array}{l}72 \min 57 \mathrm{~s} \\
\left(72^{\prime} 57^{\prime \prime}\right)\end{array}$ & $\begin{array}{llr}\text { Marina } & \text { revela } & \text { sua } \\
\text { verdadeira } & \text { história } & \text { para } \\
\text { Alberto. } & & \\
& & \end{array}$ & $\begin{array}{l}\text { Marina conta toda sua história para Alberto. } \\
\text { Revela que seus pais estão vivos no leprosário e } \\
\text { seu medo diário de acordar leprosa. Alberto } \\
\text { compreende e aceita Marina. }\end{array}$ \\
\hline 06 & $\begin{array}{l}86 \min 23 \mathrm{~s} \\
\left(86^{\prime} 23^{\prime \prime}\right)\end{array}$ & $\begin{array}{l}\text { Descoberta da morte e do } \\
\text { assassino do menino Chico }\end{array}$ & $\begin{array}{l}\text { Manuel ameaça contar publicamente para toda a } \\
\text { ilha que Marina é filha de leprosos isolados. É } \\
\text { interpelado quando os moradores descobrem que } \\
\text { ele foi o assassino do menino Chico. }\end{array}$ \\
\hline
\end{tabular}

Três momentos de alusão a lepra no filme Caiçara merecem destaque. O primeiro é a alusão aos preventórios logo no início do longa-metragem, onde a protagonista Marina lá 
Research, Society and Development, v. 9, n. 11, e100291111268, 2020

(CC BY 4.0) | ISSN 2525-3409 | DOI: http://dx.doi.org/10.33448/rsd-v9i11.11268

reside juntamente com outras meninas. Neste mesmo período, percebe-se a grande discriminação que assolava as crianças filhas de leprosos na época.

A figura do médico evidencia as relações entre a lepra e a medicina. Em uma de suas visitas ao preventório, Zé Amaro, o futuro noivo da protagonista Marina, recebe informações de um médico sobre as condições dos filhos saudáveis de leprosos isolados. A descrição dada por este profissional condiz com o grau de conhecimento que se tinha da lepra na época. Neste relato, o médico diz ao homem que, apesar de oriunda de leprosos, Marina não possuía a doença. Desta forma, o médico assegurou ao noivo que ele não estaria se casando com uma leprosa.

Um segundo momento é o relato sobre uma antiga moradora do preventório, chamada Ondina. Este relato é o mais fiel a realidade que de fato acontecia com as mulheres da época na condição de filhas de leprosos. O relato dizia respeito à dissolução do casamento de Ondina por seu marido. O preconceito e a discriminação dissolvendo laços sociais e matrimônios.

Esta era a realidade das mulheres jovens e filhas de leprosos daquele momento. Quando separadas de seus pais, estes direcionados aos asilos-colônias, as crianças e adolescentes menores de 18 anos e que não possuíam família que as acolhessem eram conduzidas aos preventórios. Nestes, passavam boa parte da infância e adolescência, de lá saindo apenas quando aptas para à vida adulta. Desta forma, os preventórios lepróticos eram orfanatos exclusivos a filhos de leprosos, e tinham por objetivo cuidar destas crianças órfãs de pais vivos. Cuidavam e marcavam suas vidas para sempre com a pecha da lepra.

No caso do filme, não há relatos sobre a faixa etária de Marina, todavia, duas possibilidades históricas poderiam ser consideradas em seu caso. A protagonista poderia ainda não ter alcançado a maior idade, ou então não teria sido acolhida pelo restante de sua família. Ou então as duas. A última possibilidade era muito recorrente na época. Um dos principais motivos era o fato de que a maioria da população não possuía conhecimento adequado acerca da lepra. Isso contribuía muito para a manutenção da discriminação recorrente com relação a lepra, que até então ditava a repulsa da sociedade considerada sã para com os leprosos e seus descendentes. Enfim, adotar uma moça filha de leprosos poderia transplantar para o restante da família a discriminação da qual ela sofria e ninguém queria que se incrustasse em sua imagem.

Contudo, o que está descrito no filme coincide com estudos históricos. O filme é lançado 1950, ano este que a política de isolamento dos leprosos está no auge no Brasil. A história dos pais da personagem Marina não é detalhada no filme. São mencionados simples e 
Research, Society and Development, v. 9, n. 11, e100291111268, 2020

(CC BY 4.0) | ISSN 2525-3409 | DOI: http://dx.doi.org/10.33448/rsd-v9i11.11268

unicamente como leprosos que residem em um asilo-colônia. O paradeiro dos pais da protagonista não foi citado, em qual leprosário estavam isolados. Um complemento à carga dramática da obra. Desta forma, os diretores do filme não se incumbiram de retratar de forma detalhada e fidedigna a realidade dos leprosos na época.

Contudo, observe-se que nas seis circunstâncias que aparece durante o filme a lepra é sempre ligada ao demérito de quem a possui (no caso os pais de Marina) e daqueles que rodeiam essas pessoas (no caso a própria Marina). A lepra pesava sobre Marina mesmo nunca tenha tido a doença. Era uma mácula que acometia a todos. Excetuando a ocasião $\mathrm{n}^{\circ} 5$, as demais a lepra é sempre uma ameaça vergonhosa que pesa sobre Marina. Um mal que o filme mostra que apenas o amor de Alberto, a paixão de Manuel e o interesse de Zé Amaro puderem transpor.

Um aspecto importantíssimo a se observar é que em nenhum momento no filme existe alguma crítica a situação de exílio sanitário vivido pelos leprosos e seus filhos. A medicina e o Estado atuaram juntos no isolamento dos leprosos, mas, nem mesmo Marina questiona ou coloca sob suspeição a prática então recorrente para com os leprosos. Ela era socialmente aceita na época, endossada socialmente, pelo Estado e pela medicina. Um ano antes, em 1949, o Brasil havia acabado de aprovar uma lei no Congresso Nacional ratificando o isolamento dos leprosos, agora com base em bases jurídicas ainda mais sólidas.

Em 1949, edita-se a lei (federal) no 610 de 13 de janeiro, que "fixa normas para a profilaxia da lepra”. Essa lei assemelha-se aos regulamentos sanitários aprovados no período da Primeira República, notadamente com o Regulamento de 1923. Contudo, com uma diferença jurídica que na década de 1960 embaraçou aqueles que pretendiam revogá-la para extirpar o isolamento. Era uma lei sancionada pelo presidente e votada no congresso nacional. Em tese, juridicamente, trata-se de uma espécie normativa, um diploma legal, hierarquicamente superior, decisão do povo, materializada por seus representantes. Para revogá-la, a priori, seria necessário outra lei do mesmo tipo. Abrahão Rotberg (médico paulista) explica o obstáculo que isso representou (Curi, 2010, p. 320).

Era preciso que o congresso votasse uma lei revogando aquela (refere-se a lei n. ${ }^{\circ} 610$ de 13/01/1949). E quem é que faria isso? Para convencer deputados e senadores que deveriam liberar o doente, com esse estigma que havia, com todas as superstições existentes, era coisa humanamente impossível. O Serviço Nacional de Lepra fez o impossível, mas conseguiu só alguns votos. Passou o governo do Jânio, a renúncia, o Jango (...) e o Parlamentarismo. Como primeiro Ministro outro mineiro, o Tancredo Neves. Este era muito inteligente, viu tudo aquilo e fez uma nova 'norma' para a prevenção da lepra, que naquela ocasião tomou o número 968 de 1962 que liberou o doente. Acabou o isolamento (Curi, 2010, pp. 319-320). 
Research, Society and Development, v. 9, n. 11, e100291111268, 2020

(CC BY 4.0) | ISSN 2525-3409 | DOI: http://dx.doi.org/10.33448/rsd-v9i11.11268

Sempre é bom lembrar que foi durante a década de 1950 que o isolamento dos leprosos começa a ser questionado. Ele foi criticado por sua ineficiência e desumanidade. Contudo, o discurso contrário gestou-se ao longo de toda a década. O filme Caiçara é de 1950. Uma crítica contundente ao isolamento só a partir do final da década. Caiçara foi lançado no auge do isolamento dos leprosos.

Entre 1945 e 1953, outros acontecimentos começaram, mesmo que indiretamente, começaram a ruir as certezas que fundamentavam o isolamento. Em 1941, o médico estadunidense Guy Henry Faget (1891-1947) divulgou a constatação do poder terapêutico das sulfonas sobre a hanseníase após um experimento realizado em Carville, um leprosário no Estado da Louisiana nos Estados Unidos. No Brasil, a sulfona foi utilizada pela primeira vez, em 1944, no asilo-colônia de Padre Bento em Guarulhos/SP. Em 1948, o V Congresso Internacional de Lepra, ocorrido em Cuba, recomendou o isolamento apenas paras as "formas contagiantes". Em 1953, o VI Congresso Internacional de Lepra, ocorrido na Espanha, recomendou que o isolamento fosse usado de maneira seletiva. Elencados dessa forma esses acontecimentos dizem muito pouco. Contudo, entre 1945 e 1953 inúmeras críticas abriram caminho para repensar a profilaxia habitual utilizada na lepra. Em 1953, o Brasil também constatava que endemia leprótica não apresenta queda desde a realização dos primeiros censos da época da Inspetoria (década de 1920). Já eram rumores e novos tempos (Curi, 2010, pp. 261-262).

Outro acontecimento que começou a pesar sobre os isolacionistas foi a postura internacional expressa nos Congressos Internacionais de Lepra (CIL), notadamente o de Madri, de 1953, que sugeria o isolamento seletivo, e o de Tóquio, de 1958, que condenava o isolamento, mesmo o seletivo, bem como, a aplicação de leis de exceção, como medidas anacrônicas (Curi, 2010, pp. 315-316).

Portanto, é seguro afirmar que o filme faz coro ao discurso da época. Entre crítico e apologético, ele figura mais no segundo polo. Nele não aparece as cenas típicas de leprosos horrendos que assustam e chocam esteticamente, como ocorre em Bem-Hur e em Diários de Motocicleta (Cf. Curi, 2014). A lepra é presença constante, mas velada, nunca explícita. Marina se olha no espelho temendo acordar leprosa todos os dias, mas o pior é apenas insinuado ao longo do filme e nunca efetivamente acontece. Quando os moradores e outras pessoas olham Marina fixamente ele leva a mão ao rosto temendo que sinais da lepra estive aflorando no seu corpo. É um trauma que ela carrega, mas no filme tal temor não se realiza.

Na ocasião n4 (71min51s), Manuel ameaça Marina com os seguintes dizeres: 
Quadro 5 - Diálogos de Caiçara - Menção nº 4 (71min51s) - Vera Cruz - 1950.

Manuel: Um momento!

Manuel: Nem se pode falar. Afinal somos sócios, não é!

Marina: Quer que você quer?

Manuel: Quer dizer que vai casar com o marinheiro. Meus parabéns.

Manuel: E já contou pra ele de onde saiu? Não! Ele já sabe que você tem lepra no sangue? Não!

Manuel: Então eu terei o prazer de contar que seus pais são dois leprosos. E que você mais dia menos também será. Se já não é.

Manuel: Vá, vá, não se preocupe. Deixe isso por minha conta.

*** Marina abandona o local do diálogo aos prantos e a cena se encerra com gargalhadas maldosos de Manиel.

Fonte: Filme Caiçara - 1950 - Elaboração dos autores.

Esta cena do filme traz uma montagem bem típica dos filmes. Momento de clímax em que o protagonista-herói é ameaçado pelo vilão que termina maldosamente rindo do que pretende fazer. Contudo, para os estudos sobre a lepra o que interessa é que esta cena evidencia, juntamente com a história de Ondina que foi informada aos espectadores logo no início do filme, que a lepra tinha potencial de alterar e redimensionar a vida das pessoas. E modificar a vida de maneira permanente. Não era uma doença como as outras que se resolvia com um período de internação hospitalar ou um tratamento medicamentoso. Também não resultava na morte. Tratava-se de uma categoria de morbidade que alterava para pior a vida das pessoas. Um mal biológico que extravasava para o social-biográfico.

\section{A Lepra na Época de Caiçara}

O filme ilustra a história e a história se reflete no filme. A produção cinematográfica Caiçara tem seu lançamento em 1950, período no qual a prática do isolamento se configurava, para medicina e para a política, como o melhor maneira de combate à lepra. Era o auge do isolamento sanitário dos leprosos no Brasil.

O Brasil, semelhante a outros países na mesma época, organizou o tripé-isolacionista estruturado, a saber, em: asilos-colônias, preventórios e dispensários. Esse sistema isolacionista englobava os leprosos, seus filhos e parentes e contatos, nesses três pilares respectivamente.

Os asilos-colônias se tratavam de colônias específicas para leprosos. Possuíam sistema político-econômico próprios, além de instituições sociais básicas, como hospital, escolas, igrejas, cinema e até mesmo cemitério. Tal iniciativa foi adotada com um objetivo de caráter 
sanitarista, isto é, frente a endemia de lepra que assolava o país, o ato de isolar os leprosos foi tido como um método profilático. Enfim, tratava-se de um isolamento sanitário.

Em consonância e em paralelo com os asilos-colônias, houve a criação dos preventórios. Tal órgão era incumbido de acolher os filhos saudáveis de leprosos ainda em menoridade, um orfanato exclusivo com a finalidade de cuidá-los e educá-los até que pudessem viver autonomamente. Quantos aos filhos doentes deveria ficar isolados nos asiloscolônias. Os filhos de leprosos saudáveis eram vistos como doentes em potencial, destarte, restringir o contato entre a sociedade tida como sã e os mesmos era um método preventivo, como o nome já pressupõe.

Para uma maior segurança desta medida profilática, houve também a criação dos dispensários. Grupos de pessoas contratadas para, de certa forma, vigiar os parentes, contatos e amigos dos leprosos, a fim de cuidar para que não houvesse contato entre as partes e assim, contaminação. Assim como as crianças dos preventórios, as pessoas monitoradas pelos dispensários só poderiam ter contato com os leprosos nos asilos e de forma planejada e monitorada e sem contato físico. No filme Marina descreve para Alberto como eram as visitas aos pais no leprosário. Inclusive, ressalta que não tinha contato físico direto com os pais e que "beijava o vidro", dado a impossibilidade de tocar sua mãe.

Ao contrário do esperado e do prometido na época a política de isolamento não resultou na diminuição da endemia de lepra. Mesmo com o extenso número de asilos-colônias criados e em atividade o número de infectados não reduziu. Ao mesmo tempo, observa-se que o isolamento passa a não ser mais considerado viável, quer pela ótica econômica, quer pela logística. O Estado percebeu que asilos para leprosos começaram a custar aos cofres públicos valores excessivos, evidenciando por fim, além da ineficiência profilática, sua desumanidade e por último, serem inviáveis economicamente.

Na época da criação e divulgação da obra cinematográfica, a maioria dos asiloscolônias já estavam construídos e em pleno funcionamento, também os preventórios e os dispensários. Na obra, os pais de Marina se encontram em um asilo-colônia, enquanto ela, ainda jovem, em um preventório. Dessa maneira, percebe uma cumplicidade respeitosa entre obra e realidade.

Assim, sempre é bom registrar e lembrar que o isolamento falhou por si só. Ainda na década de 1950, percebeu-se no Brasil, no Estado de São Paulo de forma ainda mais clara, que o isolamento não estava sendo produtivo e outra abordagem seria necessária. Continuassem isolando como estavam, mantidos os números de internações compulsórias no ritmo da época logo o Brasil precisaria de uma rede de isolamento de duas a três vezes maior 
(CC BY 4.0) | ISSN 2525-3409 | DOI: http://dx.doi.org/10.33448/rsd-v9i11.11268

do que a existente. Os custos, a desumanidade e a operacionalização disso logo inviabilizariam todo o afã isolacionista. Isso porque o isolamento, ao contrário do prometido, não atacava a causa de transmissão da lepra. Ao contrário ele estimulava as pessoas a esconderem sua doença para não verem suas vidas drasticamente alteradas.

O filme Caiçara é um elogio discreto ao isolamento, afinal Marina apesar de todo sofrimento se realiza na vida e no amor. Na época, demorou-se a perceber que cada vez que isolavam uma pessoa, separavam-na de seus filhos e marcavam com o rótulo discriminativo seus parentes e amigos, a política de isolamento sanitário da lepra afastava um outro semnúmero de leprosos que se esquivavam para evitar tamanha desgraça em suas vidas.

Foi sem dúvida um momento difícil. Na década de 1950 a urbanização se acelera no Brasil o que alardeia ainda mais a questão da lepra. Ainda não havia tratamentos medicamentosos disponíveis para tratamento em massa. Contudo, a forma como foi estruturada o combate a lepra no Brasil e no mundo a época, deu vazão e apenas incorporou e potencializou a discriminação já então existentes pra com os leprosos, agora sob chancela do Estado e da medicina. Optou-se por potencializar e ampliar a abordagem já costumeira com relação aos leprosos desde o período medieval, ao invés de buscar-se novas alternativas médicas, sociais e humanas (Cf. Curi, 2010).

\section{Marina: interseccionalidade e consubstancialidade}

O filme Caiçara é sem dúvida um típico filme romântico ${ }^{18}$. A protagonista sofre do começo do filme até bem próximo do final. Na verdade, a narrativa nos informa que o estado de sofrimento da protagonista começa com a lepra dos pais, perpassa toda a infância, adolescência e início da juventude. Depois vem o casamento, o alcoolismo e a violência do marido, as discriminações. Apenas no final do filme, e também da narrativa, vem a redenção, o final feliz. Ao término ela termina feliz no amor, ao que tudo indica, proprietária integral do próprio negócio, que herdou do marido e com a morte do sócio, aceita pela comunidade onde vive e distante do seu passado leprótico. Seria muito interessante se houvesse, pelo menos para os estudos sobre lepra, a continuação do filme, Caiçara II, pois, aí saberíamos se a lepra realmente abandonou Marina.

Contudo, a lepra sozinha não seria suficiente para explicar as agruras que sofre Marina. Ela também era mulher, órfã, pobre e desprovida de uma família que pudesse acolhêla. Enfim, ela não sofria apenas um tipo de discriminação. 
Research, Society and Development, v. 9, n. 11, e100291111268, 2020

(CC BY 4.0) | ISSN 2525-3409 | DOI: http://dx.doi.org/10.33448/rsd-v9i11.11268

Toda sociedade elabora seus próprios marcadores de diferença. Ou seja, transforma diferenças físicas em estereótipos sociais, em geral de inferioridade, e assim produz preconceito, discriminação e violência. Se o conceito de "diferença" implica reconhecer, como explica o filósofo Michel de Montaigne (1533 - 92), que "o homem é um assunto espantosamente vão, variado e inconstante", no sentido de ser rica e plural a experiência humana, o termo, na prática, tem sido mais utilizado para desqualificar (Schwarcz, 2019, p. 174).

Observe-se que a violência que Marina sofre do marido autoritário, machista e alcoólatra era uma prática recorrente no Brasil da década de 1950. Marina também era uma moça pobre, cuja família não podia ou não quis acolhê-la, e, por isso estava no preventório, e por fim era mulher o que já a colocava numa situação de dependência de um matrimônio para realizar-se socialmente. Enfim, além da lepra outras diferenciações, marcadores de diferença, pesavam sobre ela. Lepra, pobreza, orfandade e mulher eram categorias nas quais se enquadrava, enfim, discriminação da doença, de classe, de gênero e sexo.

Isso é o que contemporaneamente na teorização sobre gênero se chama de interseccionalidade. Ou seja, várias formas de discriminação se encontram, se somam, se adensam sobre determinado indivíduo. As discriminações se sobrepõem o que reforça e cristaliza o lugar social discriminado de certos indivíduos, grupos ou classes.

Notem que no filme Marina sempre necessita da mão masculina para deslocar-se socialmente ou recolocar-se. Seja Zé Amaro, para tirar-lhe do preventório, Manuel para livrarlhe do marido violento e alcoólatra, o menino Chico para livrá-la de Manuel e finalmente Alberto para conduzi-la a felicidade. Sinhá Felicidade, por exemplo, outra personagem feminina e negra, apensar de desejar reposicionar Marina, mesmo utilizando da magia, precisou de uma interferência masculina para atuar sobre o destino de Marina. Para sair do preventório, tanto ela, quanto Ondina, precisaram do matrimônio, ou seja, de um homem para assumi-las e protegê-las. Enfim, Marina sofria desse modo o que atualmente teoriza-se como discriminação de gênero.

Como os leitores e leitoras já devem ter percebido, a noção de gênero, não é propriamente um tema do pensamento social brasileiro (...). É antes uma maneira de olhar, um olhar transversal, uma leitura de entrelinhas, que busca na análise das convenções vigentes um modo de entender como as diferentes sociedades atribuem características femininas ou masculinas aos seus integrantes - quais são suas contradições, os termos em disputa e, principalmente, as questões implícitas em todas essas atribuições (Correa, 2012, pp. 115-116).

A “questão de gênero" tem, assim uma longa genealogia política - suas raízes estão na Revolução Francesa, no feminismo socialista, e anarquista, no feminismo associado ao 
Research, Society and Development, v. 9, n. 11, e100291111268, 2020

(CC BY 4.0) | ISSN 2525-3409 | DOI: http://dx.doi.org/10.33448/rsd-v9i11.11268

abolicionismo norte-americano, no feminismo inglês, de luta pelo voto - e, no Brasil, apesar de terem uma história anterior, as feministas se definiram melhor durante a luta contra a ditadura militar (Correa, 2012, p. 116).

A discussão hoje sobre interseccionalidade está bem assimilada nas Ciências Humanas, notadamente nos Estudos Culturais e nos Estudos Feministas. Contudo, é preciso reconhecer e compreender que a história de Marina não se limita e não se explica apenas recorrendo a história da lepra. Verdade também que não se pode prescindir da lepra para entender a personagem Marina e os desdobramentos que vive no filme Caiçara.

No entanto, Marina era uma só, apenas um único ser e não um feixe de identidades justapostas frouxamente ou densamente amarradas. Foi neste sentido que o texto de Danièle Kergoat foi iluminador do que ocorreu com a Marina de Caiçara e com as outras marinas que existiram no Brasil durante a Era do Isolamento dos leprosos. Kergoat prefere o termo consubstancialidade. E explica:

Em outras palavras, o termo "interseccionalidade" me incomoda por remeter ao cruzamento de categorias. O que é absolutamente legítimo para algumas utilizações, por exemplo, com a finalidade de mostrar, com fez Crenshaw (refere-se a Kimberlé Crenshaw), que as mulheres negras e pobres estavam na intersecção de vários sistemas de dominação e que essa intersecção não era considerada pelo sistema jurídico estadunidense. Mas no que me diz respeito - eu sou socióloga -, a questão não é entrecruzar categorias, mas a partir das relações sociais que fabricam tais categorias, rastrear os processos que estão na origem da produção de grupos e pertencimentos objetivos e subjetivos (Kergoat, 2016, p. 21).

Assim, a socióloga Danièle Kergoat propõe para compreender a situação de mulheres sobre as quais pesam mais de um tipo de discriminação o termo consubstancialidade, que foi adotado neste estudo. Kergoat explica que a interseccionalidade nos faz pensar de maneira aditiva e que o mais adequado seria pensamos de maneira consubstancial. Ou seja, somos um ser único substantivado, cuja construção utilizou-se de vários elementos, que são separáveis apenas intelectualmente, mas não socialmente. Assim, ela define a consubstancialidade.

Foi justamente para dar conta desses dois objetivos (compreender os sistemas de opressão e a busca por emancipação) que desenvolvi o conceito de consubstancialidade na década de 1970, a fim de "articular" sexo e classe. (...) Mas o que é a consubstancialidade? Por que não falar em interseccionalidade? Apresentarei incialmente o conceito e esclarecerei suas propriedades quanto às tensões que atravessam a reflexão sobre a articulação das relações de poder, reflexão que as vezes parece unificada com excessiva rapidez sob o termo interseccionalidade. (...) Daí a consubstancialidade. (...) Em meu entendimento, uma relação social é uma tensão em 
Research, Society and Development, v. 9, n. 11, e100291111268, 2020

(CC BY 4.0) | ISSN 2525-3409 | DOI: http://dx.doi.org/10.33448/rsd-v9i11.11268

torno da qual se criam grupos (eles não estão dados desde o início) enquanto uma teoria é apenas um marcador descritivo (KERGOAT, pp. 20/19-20/20/20).

Marina não era uma coisa ou outra; mulher ou leprosa, órfã ou pobre, ela era tudo isso ao mesmo tempo. Embora em algumas ocasiões do filme, determinadas características suas tenham mais destaque, ela era um único ser, ainda que constituído por várias identidades, como todos nós, também somos assim.

Daí adotamos aqui a consubstancialidade para pensar a personagem Marina. Confluência de várias formas de discriminação pesavam sobre ela. Nem todas as brasileiras da década de 1950 eram órfãs e pobres, nem todas tinham um passado leprótico a lhe desfavorecer. Hoje os estudos feministas já nos esclareceram também que a categoria mulher, por exemplo, não pesa sobre todas da mesma forma. Mulheres ricas tem sua vulnerabilidade diminuída, enquanto mulheres pobres a têm aumentada.

Com relação a lepra já tive oportunidade de observar a mesmíssima coisa (Cf. Curi, 2010). A lepra não pesava sobre todos da mesma forma. Pobres, negros e mulheres tinham sua lepra realçada enquanto outras pessoas devido a outros atributos tinham sua lepra esmaecida e minorada. É o incrível caso, por exemplo, de Balduíno IV, rei de Jerusalém, que apensar de leproso, permaneceu no trono e governou, ao que tudo indica, sabiamente e habilmente, até a morte. Aleijadinho em Minas Gerais é outra história de um leproso que conseguiu escapar, ressalvadas as controvérsias, da exclusão que lhe rondava. Contudo, em toda história da lepra, ninguém foi tão sagaz o suficiente para impedir que a lepra viesse a agregar-se no seu ser, a consubstanciar-se como ensina Danièle Kergoat. Ainda que fosse um rei habilidoso ou um artista fenomenal a lepra sempre deixou marcas. A lepra sempre marcou a vida de todos com os quais cruzou no caminho. Sempre interferiu nos seus destinos.

\section{Considerações Finais: A lepra e as mulheres}

O filme caiçara foi o primeiro filme da extinta Companhia Cinematográfica Vera Cruz. A ideia original era produzir um filme inteiramente nacional. Contudo, não foi possível. $\mathrm{O}$ diretor era italiano, muitos técnicos eram estrangeiros. $\mathrm{Na}$ época, e decididamente isso ficou bem claro, o Brasil não possuía quadros técnicos suficientes para uma produção inteiramente nacional. Contudo, decididamente e sem dúvida foi realizado um esforço para ser uma obra fílmica nacional. A ideia de utilizar-se de atores nacionais, alguns deles 
recrutados entre os próprios moradores do município de Ilhabela, evidencia a preocupação com a criação de um cinema nacional que aborda-se coisas brasileiras.

Quanto a lepra ela ocupa um lugar de destaque no filme, mas não central. Ela é parte do enredo e da trama da história. Ela é um fantasma que assombra Marina e todos as pessoas da época que poderiam se tornar Ondinas, Marinas ou até os pais de Marina isolados e trancados num leprosário num exílio sanitário estatal-médico.

Marina se olhava no espelho todos os dias e diariamente sentia medo de repentinamente acordar leprosa. Um medo real naquela época e não infundado. Medo de terminar como os pais. É bom lembrar que a década de 1950 foi um período próspero para o imaginário da lepra. Em 1952, Ernesto Guevara de Sierna, o futuro Che Guevara, e seu amigo Alberto Granado empreenderam uma viagem pela América do Sul na qual se deparam com vários leprosários na região (Cf. Curi, 2014). No final da década em 1959, Bem-Hur um dos filmes mais bem-sucedidos na história do cinema, também coloca a lepra em posição de destaque, assim como Caiçara e Diários de Motocicleta (anos mais tarde). Enfim, a década de 1950 foi muito produtiva para o imaginário da lepra.

Pelo filme sabemos que Marina sofreu desde o nascer. Foi órfã de Pais Vivos, casouse para livrar-se do preventório, sem amor, e viveu um matrimônio que não lhe cativou nada de bom e deteriorou-se em violência e mais sofrimento. Marina não planejou divórcio nem a fuga, sua situação de vulnerabilidade lhe dava poucas opções. No filme isso nem é cogitado. O próprio suceder dos fatos se encarrega de livrá-la dos obstáculos da vida até sua redenção final nos braços de seu amado. Uma situação rara na vida real.

O sócio do marido, Manuel da Silva, homem violento, ciumento e desejoso de casar-se com Marina se encarrega, por conta própria, de assassinar Zé Amaro, o primeiro esposo de Marina. Ela desconfia deste desfeito e tem ele confirmado depois pelo próprio Manuel, mesmo assim, num desvio ético de conduta Marina não informa as autoridades o que lhe foi revelado. O menino Chico protege Marina e Sinhá Felicidade, primeira sogra de Zé Amaro, por vingança ou por compaixão, auxilia Marina na luta contra Zé Amaro. No fim o menino Chico, morre pelas mãos de Manuel que desmascarado publicamente foge e termina morto, provavelmente suicídio.

Os obstáculos de Marina desfizeram-se sem que ela empreende-se grandes esforços. Será que a maioria das moças dos preventórios tiveram a mesma sorte de Marina? Certamente, o filme Caiçara é mais uma projeção de um sonho romântico nas telas inaugurais do cinema brasileiro do que certamente a transposição da dura realidade que acometia os 
leprosos e seus familiares nos idos anos da década de 1950; época áurea da Era do Isolamento.

Assim, decididamente o filme Caiçara é uma história romântica típica, onde o amor do casal Marina-Alberto ultrapassa barreiras, vence obstáculos para se realizar. Nem a lepra deteve tal amor. Um amor que tem opositores brutais e tirânicos, algozes assassinos e antiéticos, mas que ao final tudo supera e se realiza. Um amor que nasceu desinteressadamente e assim vicejou e prosperou, cresceu e desenvolveu-se, até que enfim, contra tudo e contra todos, realizou-se e materializou-se. Certamente a maioria das moças preventoriais terminaram como Ondinas ou como Marinas de Zé Amaro. Embora não haja levantamentos do que ocorreu com essa população, certamente as Marinas realizadas com seus Albertos foram episódicas, se não raras, certamente cinematográficas.

Afinal a lepra servia a cinematografia brasileira nascente, mas não fidedignamente. É preciso finalizar então esclarecendo aos leitores, interessados e estudiosos que a história da lepra retrata no filme Caiçara se parece pouco com o que ocorreu com os leprosos no Brasil durante o século XX e muita se assemelha aos sonhos românticos atuais e de outrora.

Para pesquisas futuras envolvendo a lepra e o cinema existem ainda vários filmes que merecem estudo e abordagem. Sobre o filme Caiçara e a lepra seria importante uma pesquisa sobre seu roteiro e as fontes de inspiração para inclusão desse tema na obra. Sobre a Vera Cruz o restante da produção e suas relações com a lepra estão inteiramente por serem estudadas.

\section{Referências}

Abad, M. L. \& Gáscon, M. L. G. (2013). Género, cultura e salud. In: Tedeschi, L. A. (Org.). Leituras de gênero e interculturalidade. Dourados: Editora da UFGD, pp.369-387.

Baczko, B. (1985). Imaginação Social. In: Enciclopédia Einaudi. Vol. 05 (Antropos-Homem), Lisboa: Imprensa Nacional/Casa da Moeda, pp.296-332.

Baecque, A. (2008). Telas: o corpo no cinema. In: Corbin, A. et alii (Dir.). História do corpo. Petrópolis: Editora Vozes, Vol. 3, pp. 481- 507.

Barret-Ducrocq, F. (Dir.). (2000). A intolerância. Rio de Janeiro: Bertrand Brasil. 
Bonventti, R. (2015). O galã descoberto na praia de Santos. Disponível em: Portal R7.Com Cartão de Visitas News (Coluna) (on-line). 30/01/15. Acesso em 02/30/2020.

Bresciani, S. \& Naxara, M. (2004). Memória e (res) sentimento: indagações sobre uma questão sensível. Campinas: Editora da Unicamp.

Bruschini, C. \& Unbehaum, S. G. (2002). Gênero, democracia e sociedade brasileira. São Paulo: Editora 34.

Buther, J. (2008). Problemas de gênero: feminismo e subversão da identidade. Rio de Janeiro: Editora Civilização Brasileira.

Callegari, J. \& Georgino, E. (2003). Vera Cruz, a Hollywood brasileira. In: Aventuras na História. São Paul: Editora Abril, Abril/03, pp. 44 a 47.

Campelo, T. (2007). Jonathas Serrano, narrativas sobre cinema. In: Cadernos de Ciências Humanas - Especiaria. 10(17), jan./jun., p. 57-76.

Catani, A. M. (2018). A Vera Cruz e os estúdios paulistas nos anos 1950. In: Ramos, F. P. et all (Org.). Nova história do Cinema Brasileiro. Vol. 1. São Paulo: Edições SESC, pp. 432453.

Chartier, R. (1990). A história cultural: entre práticas e representações. Lisboa: Difel/Bertrand.

Colling, A. M. \& Tedeschi, L. A. (Org.). (2015). Dicionário Crítico de Gênero. Dourados: Editora da UFGD.

Colling, A. M. (2014). Tempos diferentes, discursos iguais: a construção histórica do corpo feminino. Dourados: Editora da UFGD.

Correa, M. (2012). Gênero, ou a pulseira de Joaquim Nabuco. In: Botelho, A. \& Schwarcz, L. M. (Org). Cidadania, um projeto em construção. São Paulo: Editora Claro Enigma, p. 115116. 
Curi, L. M. \& Figueiredo, B. G. (2011). A lepra no Brasil colonial. Hansenologia Internationalis. Suplemento. $12^{\circ}$ Congresso Brasileiro de Hansenologia /Congresso Regional da ILA - Américas (Resumos). 36(1). ISSN: 19825161 (on-line).

Curi, L. M. \& Figueiredo, B. G. (2011). Hanseníase não é lepra. Hansenologia Internationalis. Suplemento. $12^{\circ}$ Congresso Brasileiro de Hansenologia /Congresso Regional da ILA - Américas (Resumos). 36(1). ISSN: 19825161 (on-line).

Curi, L. M. \& Figueiredo, B. G. (2011). Leprosos medievais: de "Pobres de Cristo" a “inimigos da cristandade”. Hansenologia Internationalis. Suplemento. $12^{\circ}$ Congresso Brasileiro de Hansenologia /Congresso Regional da ILA - Américas (Resumos). 36(1). ISSN: 19825161 (on-line).

Curi, L. M. \& Figueiredo, B. G. (2011). O advento da Hansenologia. Hansenologia Internationalis. Suplemento. $12^{\circ}$ Congresso Brasileiro de Hansenologia /Congresso Regional da ILA - Américas (Resumos). 36(1). ISSN: 19825161 (on-line).

Curi, L. M. (2002). “Defender os sãos e consolar os lázaros”: lepra e isolamento no Brasil (1935 a 1976). Mestrado em História. Uberlândia: UFU.

Curi, L. M. (2006). Lepra e Preventórios do Brasil: a Educação a serviço do "bem”. Revista Evidência. Araxá: Uniaraxá, 2(2),149-179.

Curi, L. M. (2008). Herdar ou contrair? História da definição etiológica da hanseníase. In: Hansenologia Internationalis. Suplemento - $11^{\circ}$ Congresso Brasileiro de Hansenologia (Resumos). Bauru: ILSL.

Curi, L. M. (2008). História da Hansenologia. Anais do XVI Encontro Regional de História da ANPUH-MG. (Anais eletrônicos). ISBN: 978-85-60087-03-7.

Curi, L. M. (2008). O corpo e a doença na História: confluências sobre a lepra. Revista ALPHA. (Patos de Minas), Unipam, 9, 82 a 99. 
Curi, L. M. (2010). Excluir, isolar e convier: um estudo sobre a lepra e a hanseníase no Brasil. Doutorado em História. Belo Horizonte: UFMG.

Curi, L. M. (2014). Che Guevara e os leprosos: vidas marcadas. In: Gomes, A. C. V. \& Carvalho, E. B. (Org). História da Ciência no Cinema V. Belo Horizonte: Editora Fino Traço, pp. 75 a 92 .

Curi, L. M. (2019). História da lepra e da hanseníase em Minas Gerais: das origens a atualidade. In: Monteiro, Y. N. (Org.). História da hanseníase no Brasil: silêncios e segregação. São Paulo: Editora Intermeios, (ISBN 978-85-8499-169-3).

Dortier, J. F. (2010). Dicionário de Ciências Humanas. São Paulo: Editora Martins Fontes, (Verbetes: Gênero e Sexualidade).

Ferro, M. (1992). Cinema e História. Rio de Janeiro: Paz e Terra.

Johnson, A. G. (1997). Dicionário de Sociologia. Rio de Janeiro: Jorge Zahar Editor.

Johnson, G. A. \& Silva, M. A. (2013). Gênero, Estado e políticas públicas na América Latina: o labirinto da emancipação. In: Tedeschi, L. A. (Org.). Leituras de gênero e interculturalidade. Dourados: Editora da UFGD, pp. 233-247.

Kergoat, D. (2016). O cuidado e a imbricação das relações sociais. In: Abreu, A. R. P.; Hirata, H.; Lombardi, M. R. Gênero e trabalho no Brasil e França: perspectivas interseccionais. São Paulo: Editora Boitempo, pp. 17 - 26.

Laplatine, F. \& Trindade, L. (2000). O que é imaginário. São Paulo: Editora Brasiliense, Col. Primeiros Passos.

Le Goff, J. (1991). O imaginário medieval. Lisboa: Editorial Estampa.

Maciel, A. C. M. D. (2008). “Yes nós temos bananas”. Cinema industrial paulista: a Companhia Cinematográfica Vera Cruz, atrizes de cinema e Eliane Lage. Brasil, anos 1950. Doutorado em História. Campinas: Unicamp. 
Maciel, A. C. M. D. (2013). Piccola Itália: os italianos da Companhia Vera Cruz. Disponível em: MAC. USP (on-line). Acesso em: 13 abr. 2016.

Maia, C. \& Puga, V. L. (Org.). (2015). História das mulheres e do gênero em Minas Gerais. Florianópolis: Editora das Mulheres.

Maia, C. (2015). Gênero e Historiografia: um novo olhar sobre o passado das mulheres. In: Caderno Espaço Feminino. 28(2) 741- 759.

Malafaia, W. V. (2012). Imagens do Brasil: o Cinema Novo e as metamorfoses da identidade nacional. (Tese de Doutorado). Rio de Janeiro: FGV.

Marson, I. \& Naxara, M. (Org.). (2005). Sobre a Humilhação: sentimentos, gestos, palavras. Uberlândia: Edufu.

Martinelli, S. (2002). Vera Cruz. São Paulo: Abooks.

Menezes, P. (2000). Imagens no(do) Brasil: a nação Vera Cruz. In: Socine (Org). Estudos de Cinema, Vol. 2 e 3, São Paulo: Editora Annablume, pp. 306 -320.

Miucci, C. (2013). História do Cinema. Disponível em: Mnemocine.com.br (on-line). Acesso em: 16 de dezembro de 2015.

Moisés, M. (2004). Dicionário de Termos Literários. São Paulo: Editora Cultrix.

Monteiro, G. S. \& Otre, M. A. C. (2008). Cinema novo contra o cinema industrial: uma análise Gramsciana. Disponível em: Intercom.org.br (on-line). Acesso em: 16 dez. 2015.

Monteiro, Y. N. (1998). Violência e profilaxia: os preventórios paulistas para filhos de portadores de hanseníase. In: Saúde e Sociedade. 7(1): 3-26, pp. 03 a 26.

Montenegro, A. T. (2010). História, metodologia, memória. São Paulo: Editora Contexto. 
Naxara, M.; Narson, I.; Brepohi, M. (2009). Figurações do Outro. Uberlândia: Edufu.

Pinsky, C. B. \& Luca, T. R. (2009). O historiador e suas fontes. São Paulo: Editora Contexto.

Pinsky, C. B. (Org.). (2005). Fontes Históricas. São Paulo: Editora Contexto.

Porter, R. \& Vigarello, G. (2008). Corpo, saúde e doenças. In: Corbin, A. et alii. (Dir.)

História do corpo. Petrópolis: Editora Vozes, Vol. 1, pp. 441- 486.

Priore, M. D. \& Amantino, M. (2011). História do corpo no Brasil. São Paulo: Editora da Unesp.

Ricoeur, P. (2007). A memória, a história, o esquecimento. Campinas: Editora da Unicamp.

Ruiz, A. (2003). O modelo de cinema legado pela Vera Cruz. In: Adami, A.; Heller, B. e

Cardoso, H. D. F. Mídia, cultura e comunicação - 2. São Paulo: Arte \& Ciência, pp. 17 - 44.

Schwarcz, L. M. (2019). Sobre o autoritarismo brasileiro. São Paulo: Companhia das Letras.

Scuro, L. (2017). A divisão sexual do trabalho e do cuidado na América Latina. In: Araújo, C. \& Gama, A. Entre a casa e o trabalho: gênero e família no Rio de Janeiro. Rio de Janeiro: ABE Editora, pp.21- 30.

Serrano, J. \& Venâncio Filho, F. (1931). Cinema e Educação. São Paulo: Melhoramentos.

Silva Neto, A. L. (2002). Dicionário de filmes brasileiros. São Paulo: Edição do Autor.

Simões, J. (2008). Cine Marabá: o cinema do coração de São Paulo. São Paulo: Clube de Autores.

Stevens, C. et alii (Org.). (2010). Gênero e feminismos: convergências (in)disciplinares. Brasília: Ex Libris. 
Swain, T. N. (2017). Esta violência que só faz aumentar... In: Revista Estudos Feministas, julho/2016- junho/2017 (Online).

\title{
Porcentagem de contribuição de cada autor no manuscrito
}

\author{
Luciano Marcos Curi - 80\% \\ Vera Lucia Puga - 10\% \\ Ana Carolina Pires das Dôres - 5\% \\ Fábia Núbia Moura e Silva - 5\%
}

\begin{abstract}
${ }^{1}$ Este artigo corresponde a um dos produtos do Estágio Pós-Doutoral realizado na Universidade Federal de Uberlândia (UFU) sob a supervisão da prof. Dr.a. Vera Lúcia Puga de 2018 a 2020. Trata-se da segunda pesquisa realizada pelo primeiro autor utilizando-se do cinema para compreensão da história da lepra. A primeira encontra-se publicada em: Curi, 2014, pp. 75 a 92.

${ }^{2}$ Fruto de esforços por parte de seu diretor Victor Lima Barreto, o filme é genuíno brasileiro, sendo o primeiro da companhia a retratar uma realidade nacional. Lançado em 1951, o filme, retrata a história de dois cangaceiros que lutam por uma professora. É o maior êxito da companhia, visto por milhares de pessoas e eleito o melhor filme de aventura em Cannes (1953). Pelo grande sucesso, lançou moda entre as mulheres francesas, que passaram a usar bolsas e sandálias ao estilo da película.

${ }^{3}$ Drama italiano com direção de Roberto Rossellini. Teve indicações para prêmios como Prêmio Leão de Ouro para o diretor Roberto Rossellini, sendo agraciado, somente como Prêmio Fita de Prata de Melhor Atriz Estrangeira para a atriz protagonista Ingrid Bergman.

${ }^{4}$ Para se ter uma ideia do alcance e da fama que os atores da Vera Cruz alcançaram um exemplo fortuito ilustra adequadamente a questão. O palestrante, filósofo e professor Mario Sergio Cortella, um dos mais conhecidos na atualidade no Brasil, tem seu nome inspirado no galã de Caiçara o marinheiro Alberto. Sua mãe já havia se decidido que seu filho se chamaria Mario e quando conheceu o filme Caiçara decidiu-se então adicionar o segundo nome Sérgio, ficando então, o seu recém-nascido filho com o mesmo nome do galã cinematográfico. Agradeço ao próprio professor Mario Sergio Cortella por gentilmente me confirmar essas informações por email.
\end{abstract}

5 Agradeço a senhora Denise Puertas de Araujo do COMPAHC-SBC (Conselho Municipal do Patrimônio Histórico e Cultural de São Bernardo do Campo) pelas informações valiosas sobre o Estúdio e Pavilhão Vera Cruz. Devido a inexistência de uma historiografia bem consolidada sobre o prédio da Vera Cruz elaborei uma cronologia do local que segue em apêndice no final deste artigo. Entendo, que pela importância do local para a história do cinema brasileiro, este patrimônio merece e carece do tombamento em âmbito estadual e federal. Isso para sua maior segurança, reconhecimento e utilização adequadas.

${ }^{6}$ Essa expressão foi introduzida pela revista O Cruzeiro em reportagem de 24/10/1959. A revista O Cruzeiro era ilustrada e foi fundada por Assis Chateaubriand e começou a circular em 10 de novembro de 1928 com uma tiragem de 50 mil exemplares. Com sede no Rio de Janeiro, chegou a circular, na década de $1950 \mathrm{com} 750$ mil exemplares. Destacou-se por suas grandes reportagens, seções como "O Pif-Paf" e "O amigo da onça" e a realização de eventos como o concurso Miss Brasil. Deixou de circular em 1975, para ressurgir em 1979 já com outros proprietários. Desapareceu definitivamente em 1981. A importância dessa revista no cenário brasileiro, em termos comparativos, equivale à importância que a Revista Veja, da Editora Abril, teve na década de 1990.

${ }^{7}$ Neste livro equivocadamente o nome de um dos personagens principais foi escrito incorretamente. Escreveu-se Zé Américo ou invés de Zé Amaro. Neste artigo ao fazer uma citação da referida publicação procedeu-se a devida correção.

${ }^{8}$ Outro equívoco da citação. Os doentes de lerpa eram isolados em asilos-colônias e não em dispensários. Cf. Curi, 2010.

${ }^{9}$ Essa periodização corresponde a inauguração da primeira instituição médica para isolamento de leprosos no Brasil, em 1924, e as últimas internações compulsórias registradas, em 1986.

${ }^{10}$ Trata-se do primeiro diálogo do filme que ocorre logo no início no intervalo entre $02 \mathrm{~min} 08 \mathrm{~s}$ e $04 \mathrm{~min} 04 \mathrm{~s}$.

${ }^{11}$ Colega de Marina no Preventório. Personagem não identificada (não-nomeada) interpretada por Maiza Pereira de Almeida.

${ }^{12}$ Colega de Marina no Preventório. Personagem não identificada (não-nomeada) interpretada por Célia Biar. 
${ }^{13}$ Colega de Marina no Preventório. Personagem não identificada (não-nomeada) interpretada por Eunice Faro.

${ }^{14}$ Colega de Marina no Preventório. Personagem não identificada (não-nomeada) interpretada por Cecília Machado.

${ }^{15}$ Cf. Silva Neto, 2002, pp. 142- 143; Cinemateca Brasileira. Categoria: Longa-metragem/Sonoro/ficção - 1950 - Registro em 27/09/1950. Elencamos também no elenco alguns personagens que são importantes para compreender a relação da lepra com a década de 1950 e que são apenas citados no filme, ainda que não interpretados, como, por exemplo, a moça Ondina.

${ }^{16}$ Veja no site da Cinemateca Brasileira conforme ficha de registro do filme: Cf. Cinemateca Brasileira. Categoria: Longa-metragem/Sonoro/ficção - 1950 - Registro em 27/09/1950.

${ }^{17}$ Aqui, inclusive, o primeiro autor deste trabalho reformula sua postura já adotada noutros estudos anteriores.

${ }^{18} \mathrm{O}$ conceito de romântico é motivo de variados debates e concepções entre os estudiosos. Isso porque este conceito deriva de romantismo que é assunto deveras extenso e controverso como bem ensina Massaud Moisés em obra de referência. A história é longa mais no geral considera-se o romantismo como uma derivação história da arte românica surgida na Europa Ocidental no final do período medieval. Essa arte primava pelo sentimental, escrita em prosa e em línguas românicas, e não em latim, daí o termo arte românica. Já o romantismo seria um produto moderno que reconfigurou e fez retomar a cena elementos das artes românicas, como os romances de cavalaria medievais. Segundo Massaud Moisés "como o Romantismo, principiou a Idade Contemporânea" e para este autor o movimento do romantismo tem importância equivalente a Renascença no final do período medieval, ou seja, ambos marcam o fim de uma época e sua cultura e a emergência de novos estilos e comportamentos. Assim, a partir do final do século XVIII, considera-se o romantismo como uma ampla gama de movimentos intelectuais que tendiam, de formas e graus diferentes, a fazer prevalecer o sentimento sobre a razão e a imaginação sobre a análise crítica. Temas como nacionalismo e uma criação artística mais livre e independente das tradições clássicas greco-latinas foram bandeiras do romantismo na sua vertente literária e intelectual. Aqui neste trabalho optou-se pela significação já dicionarizada do termo romântico: "Que emociona como nos romances; que expressa poesia, cenas amorosas: filme romântico.[...] Particular das cenas amorosas, poéticas; apaixonado.[...] Que, nas ideias, no caráter ou no temperamento, revela algo de apaixonado, de nobre, de lírico, que o eleva acima do prosaico, do cotidiano." Cf. Dicionário Online de Língua Portuguesa Dicio - Consulta em 08/06/2020 - Verbete: Romântico; Moisés, Massaud. 2004.

\section{APÊNDICE I - - CRONOLOGIA - ESTÚDIOS E PAVILHÃO VERA CRUZ}

04/11/1949 - O Estúdio Vera Cruz foi inaugurado em 04/11/1949 por Franco Zampari e Francisco Antônio Paulo Matarazzo Sobrinho (mais conhecido como Ciccillo Matarazzo), em um terreno de uma antiga granja em São Bernardo do Campo (doado por Ciccilo). A Vera Cruz foi a terceira companhia cinematográfica implementada no Brasil (antes existiram as cariocas Cinédia - antiga Cinearte - e Atlântida). Revelou e projetou grandes nomes do cinema, como Tônia Carrero, Anselmo Duarte, Eliane Lage, Marisa Prado e Renato Consorte. O lema da nova companhia era "Do planalto abençoado para as telas do mundo" e ambicionava uma "produção brasileira de padrão internacional". O objetivo do projeto Vera Cruz era ser uma espécie de Hollywood Brasileira, uma fábrica de filmes, ou seja, cinema industrial brasileiro de alta qualidade.

1950 - Lançamento de Caiçara o primeiro filme da Vera Cruz. Ao todo a companhia produziu dezoito filmes e alguns documentários. 
1954 - Falência da Cia Vera Cruz. O Banespa (Banco do Estado de São Paulo), que havia cedido vários empréstimos ao empreendimento assume o controle acionário e empresarial da empresa, incluindo seus filmes.

1955 - Empréstimo autorizado pelo Presidente do Brasil, Café Filho, através do Banco do Brasil, com o intuito de reerguer a Companhia Vera Cruz, foi insuficiente.

1955 a 1959 - O Banespa nomeia Abílio Pereira de Almeida diretor-superintendente que juntamente com antigos funcionários, produtores e técnicos da Vera Cruz criam a empresa Brasil Filmes que opera nas instalações da Vera Cruz em São Bernardo do Campo, porém agora com outra razão social. Neste período foram produzidos oito filmes. Operando com gastos elevados a ruína final da Brasil Filmes veio com os prejuízos colossais do filme Ravina (de Rubem Biáfora de 1959).

1959 a 1966 - Neste período o Banespa nomeia Cássio Egídio de Carvalho para administrar a Vera Cruz que deixa de ser uma produtora de filmes e passa a ser uma locadora. Cria-se uma tabela com os preços de aluguel de estúdios e equipamentos. Walter Hugo Khouri torna-se um dos seus principais clientes. Além disso, os estúdios passaram a ser utilizados para a gravação de telenovelas da extinta TV Excelsior, destacando-se, entre elas, Redenção (1966).

1966 - Novela Redenção da extinta TV Excelsior, considerada a mais longa da TV brasileira, foi gravada na área dos Estúdios Vera Cruz.

1967 - A Vera Cruz paralisou novamente suas atividades em função de embargo feito pelo Banespa, principal credor de suas dívidas.

1967 a 1972 - Em 1967, os irmãos Walter Hugo Khouri e William Khouri assumem o controle acionário da Companhia Vera Cruz e obtém o direito de usufruto do parque técnico da empresa. O regime de comodato possibilita inúmeras co-produções com companhias distribuidoras internacionais, entre as quais $O$ Palácio dos Anjos (1970), dirigido Walter Hugo Khouri. A continuidade da empresa tornou-se inviável e ela foi embargada pelo Banespa por falta de pagamento e retorna ao controle do banco.

1972 - Fechamento e encerramento das atividades da Vera Cruz. Depois de várias crises financeiras, os estúdios encerraram suas atividades em 1972.

1972 a 1975 - A Vera Cruz funcionou como almoxarifado do Banespa.

1975 - Em meados deste ano a Vera Cruz foi vendida para o grupo britânico Incorporadora Mackenzie Hill, que derruba um dos galpões com a intenção de construir um Shopping Center no local. Isso gerou uma mobilização popular e da classe artística contra o empreendimento que resultou na intervenção da prefeitura de São Bernardo do Campo. Um dos articuladores da luta pela preservação da Vera Cruz foi Walter Hugo Khouri.

1975 - Município de São Bernardo do Campos adquire a Vera Cruz mediante uma permuta de terrenos realizada então com o grupo britânico Incorporadora Mackenzie Hill. 
1975 - Prefeitura de São Bernardo do Campo realiza empréstimo com o Banespa para investir no Parque Industrial dos Imigrantes. Como garantia do empréstimo oferece o Pavilhão Vera Cruz.

1981/1982 - Dívida da Prefeitura de São Bernardo do Campos com o Banespa não foi paga e o banco aciona a cobrança judicial e o Pavilhão Vera Cruz fica ameaçado novamente de ir a leilão.

1981/1982 - Renegociações da dívida da Prefeitura de São Bernardo do Campos com o Banespa afastam o temor de leilão do Pavilhão Vera Cruz.

1987 - Tombamento histórico pelo Compahc da antiga Cia Cinematográfica Vera Cruz. Criada em 1949, por Franco Zampari e Ciccilo Mararazzo, em uma antiga granja no município. Em função de seu valor como espaço referencial da memória artístico-cultural, foi tombado todo o complexo, da sua importância nacional na história do cinema brasileiro. Lei municipal de $\mathrm{SBC}^{\circ}$ 2887, de 29/05/87.

Décadas de 1980 e 1990 - Durante todos esses anos o Pavilhão Vera Cruz serviu como espaço de eventos, convenções e feiras diversas.

1989 a 1991 - Realizada uma tentativa de revitalização do espaço. A ideia era a implantação de um centro cultural, a partir de um projeto arquitetônico desenvolvido pela arquiteta Lina Bo Bardi (1914 - 1992), responsável pelo projeto do MASP e SESC Pompeia, mas o projeto não foi adiante.

Agosto/1998 - Uma nova tentativa de revitalização da Vera Cruz, intitulada Projeto Nova Vera Cruz, ocorreu através de um convênio entre a Prefeitura do Município de São Bernardo do Campo, Governo do Estado de São Paulo e a Fundação Padre Anchieta, para a continuidade do projeto. O espaço da Vera Cruz inclusive foi cedido ao governo estadual nesta ocasião. As obras chegaram a ser iniciadas, com a construção do anfiteatro, mas não houve continuidade por falta de verbas e desmobilização por parte do Governo do Estado.

Março/2003 - O projeto Nova Vera Cruz terminou. O governador Geraldo Alckmin não pretende dar continuidade ao convênio firmado em 1998 entre São Bernardo, Estado e Fundação Padre Anchieta para reconstruir os estúdios da Cia. Vera Cruz. Ele afirmou sua posição semanas atrás ao ex-prefeito de São Bernardo, Maurício Soares. "Alckmin disse que não compensa, fica muito caro, que o governo dele tem outras prioridades. Então, o convênio está para ser desfeito", afirmou Soares.

2003 - Algumas poucas cenas do filme brasileiro Carandiru (2003) são gravadas no Estúdio Vera Cruz.

2010 - Algumas poucas cenas do filme brasileiro, Lula, o Filho do Brasil (2010) são gravadas no Estúdio Vera Cruz.

23/06/2015 - Realiza-se um contrato de concessão por 30 anos do Estúdio e Pavilhão Vera Cruz para a Telem S.A. (Técnicas Eletro Mecânicas). 
06/08/2015 - Lançamento de Projeto de Revitalização do rebatizado Estúdio e Pavilhão Vera Cruz, empreendimento financiado com dinheiro privado através de uma parceria públicoprivada. As empresas consorciadas deveriam investir cerca de 156 milhões de reais em ampliações e reformas.

03/04/2017 - Rescisão do contrato com a Telem que não cumpriu o acordado em 2015. Prefeitura de SBC reassume os Estúdios Vera Cruz.

2017 - São Bernardo vem sendo palco para grandes gravações desde a retomada do Estúdio Vera Cruz pela prefeitura em parceria com a Endemol. Em 2017, apresentadores como Luciano Huck, Gugu Liberato e Xuxa Meneguel já filmaram no local, além de outros nomes famosos já tiveram passagem no Vera Cruz, como a modelo Gisele Bündchen, o jogador de futebol Neymar e músico Carlinhos Brown.

2019 - Parte do terreno da Vera Cruz é cedida ao SESC para construção de uma unidade em São Bernardo do Campo. 